\title{
The Polar Night Shift: Annual Dynamics and Drivers of Microbial Community Structure in the Arctic Ocean
}

Matthias Wietz ${ }^{1 *}$, Christina Bienhold ${ }^{1}$, Katja Metfies ${ }^{2}$, Sinhué Torres-Valdés ${ }^{3}$, Wilken-Jon von Appen $^{4}$, Ian Salter ${ }^{1,5}$, Antje Boetius ${ }^{1, *}$

${ }^{1}$ HGF-MPG Group for Deep Sea Ecology and Technology, Alfred Wegener Institute Helmholtz Centre for Polar and Marine Research, Bremerhaven, Germany

${ }^{2}$ Polar Biological Oceanography, Alfred Wegener Institute Helmholtz Centre for Polar and Marine Research, Bremerhaven, Germany

${ }^{3}$ Marine BioGeoScience, Alfred Wegener Institute Helmholtz Centre for Polar and Marine Research, Bremerhaven, Germany

${ }^{4}$ Physical Oceanography of the Polar Seas, Alfred Wegener Institute Helmholtz Centre for Polar and Marine Research, Bremerhaven, Germany

${ }^{5}$ Faroe Marine Research Institute, Tórshavn, Faroe Islands

*corresponding authors

Matthias Wietz (matthias.wietz@awi.de)

Antje Boetius (Antje.Boetius@awi.de) 


\section{ABSTRACT}

Change is a constant in the Arctic Ocean, with extreme seasonal differences in daylight, ice cover and temperature. The biodiversity and ecology of marine microbes across these extremes remain poorly understood. Here, using an array of autonomous samplers and sensors, we portray an annual cycle of microbial biodiversity, nutrient budgets and oceanography in the major biomes of the Fram Strait. In the ice-free West Spitsbergen Current, community turnover followed the solar cycle, with distinct separation of a productive summer state dominated by diatoms and carbohydrate-degrading bacteria, and a regenerative winter state dominated by heterotrophic Syndiniales, radiolarians, chemoautotrophic bacteria and archaea. Winter mixing of the water column replenishing nitrate, phosphate and silicate, and the onset of light were the major turning points. The summer succession of Phaeocystis, Grammonema and Thalassiosira coincided with ephemeral peaks of Formosa, Polaribacter and NS clades, indicating metabolic relationships between phytoplankton and bacteria. In the East Greenland Current, ice cover and greater sampling depth coincided with weaker seasonality, featuring weaker bloom/decay events and an ice-related winter microbiome. Low ice cover and advection of Atlantic Water coincided with diminished abundances of chemoautotrophic bacteria while Phaeocystis and Flavobacteriaceae increased, suggesting that Atlantification alters phytoplankton diversity and the biological carbon pump. Our findings promote the understanding of microbial seasonality in Arctic waters, illustrating the ecological importance of the polar night and providing an essential baseline of microbial dynamics in a region severely affected by climate change.

\section{INTRODUCTION}

Microbes have fundamental roles in the marine biosphere and have been recognized as key components in global change biology ${ }^{1,2}$. Understanding the causes, complexity and consequences of microbial community dynamics requires continuous records in their environmental context. Time-series observations are beginning to discern the temporal variability and environmental drivers of marine microbiomes from diurnal to decadal $\operatorname{scales}^{3,4}$, but have mostly focused on temperate and tropical waters to date ${ }^{5-13}$. In contrast, temporal records from the polar oceans are rare. Pioneering studies have identified variable numbers, activities and community structures of polar microbes over time and space ${ }^{14-21}$, yet with limited temporal or spatial resolution.

Due to the extreme winter conditions, year-round sampling in polar waters requires autonomous observations, recently providing the first comprehensive annual records in the Arctic and Antarctic $^{22,23}$. Such approaches can identify transition phases in the interplay between ocean 
physics and the ecosystem, for instance the onset of the spring bloom or the end of net-growth. In this regard, the polar night is of key interest, when physical mixing ${ }^{24-26}$ and microbial recycling of detrital and inorganic matter 27,28 replenishes nutrients to fuel the subsequent phytoplankton bloom. Arctic phototrophic taxa are thought to persist in dormancy ${ }^{29}$, responding rapidly when light and stratification return ${ }^{30}$. Yet, microbial dynamics during the polar night within the oceanographic context remain virtually unknown.

Here, using an array of autonomous samplers and sensors, we portray microbial and oceanographic seasonality in the two major biomes of the Fram Strait. This main deep-water gateway to the central Arctic Ocean harbors the northward, permanently ice-free West Spitsbergen Current (WSC) and the southward, cold East Greenland Current (EGC) inside the marginal ice zone, with some recirculation in central Fram Strait (Fig. 1a). Our study is embedded in the long-term HAUSGARTEN and FRAM observatories studying primary productivity, benthopelagic coupling and deep-sea ecology since the $1990 \mathrm{~s}^{31,32}$. The recent deployment of autonomous devices provides a key advance to characterize complete annual cycles, expanding on summertime snapshots of microbial diversity, biogeography and activity ${ }^{33-39}$. Annual records are also important to understand biological responses to the northward expansion of subarctic habitats, often coined Atlantification, which propagates through the entire food web ${ }^{40,41}$.

Here we investigated how the influence of polar day and night shape seasonal shifts, expecting considerable differences between summer and winter microbiomes. We hypothesize that phototrophy- and heterotrophy-dominated periods in the ice-free WSC harbor markedly dissimilar microbial communities, while sea ice cover in the EGC favors winter-type communities year-round. This study improves the understanding of seasonal microbial biodiversity, the ecological importance of the polar night, and the effects of Atlantification in different areas of the Arctic Ocean. These insights are a key baseline to understand natural variability and human impact in a marine region under severe threat by climate change ${ }^{42-45}$, offering important perspectives on the present and future Arctic Ocean.

\section{RESULTS AND DISCUSSION}

The present study elucidates microbial and oceanographic seasonality in the West Spitsbergen Current (WSC) and the East Greenland Current (EGC) of Fram Strait using automated, high-frequency sampling (Fig. 1a). For this purpose, seawater was autonomously collected and preserved in situ using moored Remote Access Samplers (RAS) in weekly to monthly intervals (Supplementary Table S1). In addition, oceanographic sensors continuously recorded temperature, salinity and oxygen concentration, informing about oceanographic 
conditions including the proportions of Atlantic Water (AW) and Polar Water (PW). After recovery, water samples were subjected to molecular fingerprinting of microbial communities and quantification of inorganic nutrients. Relative abundances of bacterial, archaeal and eukaryotic amplicon sequence variants (ASVs) were then evaluated in the oceanographic context, including satellite-derived sea ice and chlorophyll concentrations (Supplementary Table S1).

\section{Major annual dynamics and drivers}

Environmental conditions and microbial community structure differed substantially between the two sampling sites (Fig. 1b, Extended Data Fig. 1-2). At the WSC mooring, ice-free AW prevailed throughout the year, with gradual physicochemical changes along the alternating stratification and mixing of the water column ${ }^{46,47}$. At the EGC mooring, deployed at the edge of the marginal ice zone, the intermittent advection of AW resulted in dynamic changes between polar (cold/ice-rich) and atlantified (warmer/low-ice) conditions (Fig. 1b). PW-dominated periods showed a typical physicochemical and microbial signature, whereas AW advection resulted in greater similarities to the WSC (Extended Data Fig. 1). This connection was strongest between AW proportions and bacterial composition (Extended Data Fig. 2; Spearman's rho $=0.4$, $p=0.00008$ ). The EGC-RAS was deployed at $80 \mathrm{~m}$ depth to avoid collision with sea ice, i.e. located in the stratified halocline below the productive layer, compared to the WSC-RAS deployed at $25 \mathrm{~m}$ in the productive layer. Hence, differences between the WSC and EGC relate to hydrography and ice cover as well as sampling depth.

Nonetheless, the WSC and EGC shared a number of fundamental patterns in microbial diversity and community turnover. Microbial communities showed major compositional shifts over the annual cycle (Fig. 2a), with substantial month-to-month variability (PERMANOVA, $R^{2} \geq 0.6$, $p<0.01$ ) indicating dynamic microbiome structures year-round. With reference to the first sampling event, communities were most dissimilar around the March equinox before becoming more similar again towards peak polar day (Fig. 2b), illustrating light-driven temporal recurrence ${ }^{48}$. Notably, bacterial but not eukaryotic alpha-diversity correlated with daylight hours in both regions (Spearman's rho $=0.6, p<0.006)$.

\section{Microbial and environmental seasonality}

We contextualized major shifts and patterns in microbial and physicochemical variability (Figs. 2-4) to delineate the four seasons: spring (mid-April to mid-June), summer (mid-June to late-July), autumn (August to October) and winter (November to mid-April). Comparing all sampling events, community structures largely clustered by season and less by site (Extended Data Fig. 3). Hence, seasonality was overall a stronger driver than geographic distance, 
oceanographic differences and sampling depth. Each season showed a characteristic oceanographic and microbial signature (Figs. 3-4, Supplementary Table S2), supported by season-specific correlations between microbial taxa and environmental parameters (Extended Data Fig. 4). Winter microbiomes were most distinct, with up to $\sim 60 \%$ compositional dissimilarity to the other seasons. Greater seasonal contrasts in eukaryotic composition underlined the structuring role of light (Fig. 3b). In line with recent metagenomic evidence, these patterns indicate a considerable degree of temporal and functional specialization ${ }^{49}$.

The WSC showed pronounced seasonality, both regarding environmental conditions (Fig. 3a) and microbial community composition (Fig. 3b). Daylight hours and temperature were the major drivers of eukaryotic variability $\left(R^{2}=0.2\right.$ respectively), whereas bacterial composition varied mostly with temperature $\left(R^{2}=0.4\right.$; PERMANOVA, $\left.p<0.001\right)$ as previously observed in global TARA microbiomes ${ }^{50}$. Bacterial alpha-diversity peaked at the end of winter (Fig. 2b) when water temperatures were lowest (Fig. 1b), underlining the day-night shift as key transition event. ASVs associated with Bacillariophyta (i.e. diatoms) and Flavobacteriales predominated from spring to autumn (Fig. 2a), likely corresponding to metabolic interrelations through algal carbohydrates ${ }^{51}$. In contrast, heterotrophic eukaryotes (foremost Syndiniales and RAD-C radiolarians), archaea (Nitrosopumilales) and specific bacteria (e.g. Rhodospirillales) predominated in winter, with additional short-lived peaks of the diatom parasites Pirsonia and MAST (Fig. 2a). We consider these taxa as "microbial recyclers" persisting on detrital, inorganic or semi-refractory substrates $^{26,52}$. The separation between photoautotrophy- and heterotrophy-driven periods of production and recycling were reflected in nutrient concentrations, with depletion in summer and replenishment during winter (Fig. 1b, Supplementary Table S1).

In the EGC, changes between polar and atlantified conditions happened on shorter time scales than seasons, causing a more variable community composition, turnover and diversity (Figs. 2-3). For instance, environmental conditions during AW advection in January resembled those in August (Figs. 1b, 3a). Daylight, temperature, hydrography and ice cover interrelated to comparable extents with microbial community structure (PERMANOVA, $R^{2}=0.1$ for each factor, $p<0.05)$. Constant proportions of photoautotrophic and heterotrophic eukaryotes year-round, with $\sim 50 \%$ lower sequence abundances of diatoms than in the WSC (Fig. 2a, Extended Data Fig. 5), indicated a different food web structure. Low irradiance due to sea ice presumably repressed primary production at the surface, while simultaneously seeding diatoms and microbes into the underlying water (discussed in detail below). Furthermore, we observed a temporal lag in the occurrences of several taxa compared to the WSC. For instance, Thioglobaceae and SAR86 occurred in EGC-summer compared to WSC-spring; or Mediophyceae in EGC-autumn compared 
to WSC-summer (Fig. 4). Hence, microbial communities in the WSC and EGC can be variable across and within seasons, with temporal shifts resulting from later phytoplankton growth and the deeper RAS location. In the following, we present a detailed synopsis of seasonal patterns and specific events in chronological order from autumn 2016 to summer 2017.

\section{Autumn}

Autumn in the WSC was characterized by nitrate, silicate and phosphate depletion and a specific community of Coscinodiscophyceae, Ceratiaceae, SAR116 and Rhodobacteraceae (Figs. 4-5, Supplementary Table S2). These patterns resemble a post-bloom state, with growing decay of summer phytoplankton ${ }^{53}$ and concurrent increase in mixotrophic dinoflagellates such as Tripos $^{54}$. The prevalence of Corethron, Rhizosolenia and Proboscia sequences (Fig. 5b, Extended Data Fig. 5) matched microscopic cell counts in the Fram Strait ${ }^{55}$, corroborating our ampliconbased results. Similar autumn patterns in the Southern Ocean indicate bi-polar seasonal preferences of Coscinodiscophyceae diatoms, likely facilitated by their ability to overcome silicate limitation ${ }^{56}$, use ammonium instead of nitrate ${ }^{22}$, and resist grazing ${ }^{57}$. Appearance of chytrid fungi and fungi-like Labyrinthulaceae at maximal nutrient depletion in October (Extended Data Fig. 6) indicates saprophytic activity on decaying algae ${ }^{58-60}$. Among bacteria, up to 13-fold higher abundances of Cand. Puniceispirillum and other SAR116 members as well as the Rhodobacteraceae taxa Ascidiaceihabitans, Amylibacter and Planktomarina (Fig. 5b) were probably fueled by DMSP and senescence compounds from decaying phytoplankton ${ }^{61-63}$. Detection of Luteolibacter from the Rubritaleaceae family (Fig. 5b) suggested concurrent particle formation, typical processes in ageing phytoplankton ${ }^{64}$ as observed in coastal Svalbard ${ }^{65}$.

Fragilariopsis co-occurred in the WSC and the EGC during early autumn (Fig. 5b). We hypothesize that this typically ice-associated taxon was transported to the WSC by advection, considering the higher proportion of PW during this time (Fig. $5 \mathrm{c}$ ). This event also covaried with higher $\mathrm{pH}$, with potential metabolic effects on prevalent taxa such as Pseudo-nitzschia ${ }^{66,67}$. Otherwise, the EGC displayed quite different dynamics. Peaking diatom abundances characterized autumn as major photosynthetic period (Fig. 4, Extended Data Fig. 5), featuring SAR86 characteristic of WSC-spring (Fig. 4). We attribute this late bloom to the minimum ice cover in autumn (Fig. 1b, Supplementary Table S2), enhancing light penetration, melt-induced stratification and ice seeding ${ }^{68,69}$.

\section{Winter}

The WSC and EGC shared elevated abundances of Magnetospiraceae, Nitrospinaceae, the Arctic97B-4 clade and unclassified Gammaproteobacteria (Figs. 4, 5b), although winter-summer 
contrasts of these taxa were stronger in the WSC (average Kruskal-Wallis significance $p \leq 0.003$ vs. 0.02 in the EGC). Furthermore, Dadabacteriales co-occurred from February (WSC) or late March (EGC) and might contribute to the recycling of microbial and other organic matter ${ }^{70}$. Fundamental regional differences were the heterotrophic "recycling state" in the WSC compared to ice-related microbial signatures in the EGC.

\section{Heterotrophic winter communities of the WSC}

The increase of Syndiniales, parasitic recyclers of phytoplankton biomass ${ }^{71-73}$, in November marked the onset of winter. Bacterial diversification and nutrient replenishment (Figs. 2, 5, Extended Data Fig. 6) followed the breakdown of summer stratification ${ }^{74,75}$, with highest mixing of the water column in January (Fig. 5a). At this time, heterotrophic eukaryotes constituted up to $\sim 70 \%$ of sequences and nutrient standing stocks were restored (Fig. 2a, 5a). The parallel decline of phototrophs to a combined relative abundance of $<5 \%$ (Extended Data Fig. 5) indicated complete mixing as one central turning point of the annual cycle, emphasizing the ecological importance of Arctic winter ${ }^{24}$. Notably, this also illustrates that only a small "seed bank" overwintered to initiate the following spring bloom. The upward transport of microbes during mixing likely enriched the metabolic potential ${ }^{76,77}$. For instance, appearance of deep-water RAD radiolarians $^{78}$ possibly contributed to the recycling of phytoplankton biomass. Stratification potentially also influenced the temporal succession of different Syndiniales clades over winter (Extended Data Fig. 6).

The co-occurrence of Nitrosopumilaceae and Nitrospinaceae (Figs. 4, 5b), the major drivers of marine nitrification, suggests an interactive niche with initial oxidation of ammonia or urea by Nitrosopumilaceae and subsequent nitrite oxidation by Nitrospinaceae ${ }^{79-81}$. In addition, the Magnetospiraceae family (Rhodospirillales) might recycle nitrogen by fixation and contribute to a yet underestimated nitrogen source ${ }^{82,83}$, although no related nitrogenase sequences were yet detected in the Arctic $^{84}$. Furthermore, metaproteomic data indicate that Magnetospiraceae also perform $\mathrm{CO}_{2}$ fixation and thiosulfate oxidation ${ }^{82,85,86}$. Genomic and metabolic evidence from other Arctic and Antarctic winter microbiomes suggests consistent roles of Nitrosopumilaceae, Nitrospinaceae and Magnetospiraceae during winter at both poles ${ }^{19,27,87-93}$. Further potential recyclers are the Pirellulaceae and Woeseiaceae through ammonia oxidation and denitrification respectively ${ }^{94,95}$. The winter niche of the poorly described Defluviicoccales clade is potentially fueled by stored glycogen ${ }^{96,97}$ or unsaturated aliphatics ${ }^{98}$. Overall, the observed elevated abundances of diverse heterotrophic and chemoautotrophic taxa highlight the polar night as an important recycling phase before the spring bloom. Furthermore, the polar night microbiome is not static, but responsive to certain stimuli such as mixing. 


\section{The microbial winter loop in the EGC}

Unique to the EGC was the persistence of raphid-pennate diatoms and flavobacteria throughout winter (Fig. 4), contrasting their light-controlled seasonality in the WSC. We attribute these signals to ice melt and repeated seeding events, following intermittent water temperatures of $>2^{\circ} \mathrm{C}$ during AW advection in January (Fig. 1b). The diatoms Bacillaria and Naviculales, together with Polarella flagellates and Chrysophyceae, constituted up to $15 \%$ of sequences after the ice melt between February and March (Fig. 5b, Extended Data Fig. 7a). All of these taxa occur in sea ice and the underlying water ${ }^{60,99-102}$, suggesting an ice-dependent heterotrophic food web. Ice algae produce copious amounts of storage polysaccharides and extracellular polymeric substances, fueling bacterial growth in the underlying water ${ }^{69,103}$. Bacillaria exudates are a valuable nutrient source for bacteria $^{104}$, as is chrysolaminarin from diatoms and Chrysophyceae ${ }^{105,106}$. The flavobacterial winter assemblage largely corresponded to a Flavobacterium ASV constituting $\sim 10 \%$ between January and March (Fig. 5b, Extended Data Fig. 7a). This ASV shared $>99 \%$ 16S rRNA similarity with Flavobacterium frigidarium, a psychrophilic genus with laminarinolytic abilities ${ }^{107}$. Detection of related sequences on ice-algal aggregates $^{60}$ supports a presumed niche through utilization of ice-algal carbohydrates. Overall, these light-independent, ice-fueled processes might explain signatures and activities of specific microbial taxa in other Arctic regions under warming ${ }^{108-110}$.

An EGC-specific winter taxon was the SAR406 clade, peaking at $9 \%$ relative sequence abundance in March and remaining detectable until summer. In addition, the frequently iceassociated genus Colwellia increased from February until a major bloom of $>20 \%$ in mid-June (Figs. 5b, 6a). We propose that the average ice cover of $\sim 60 \%$ between February and July (Supplementary Table S2) sustained these winter taxa. Both SAR406 and Colwellia markedly correlated with ice cover (Spearman's rho $=0.7, p<0.0004$ ), highlighting the role of sea ice for microbial biodiversity in polar regions. SAR406 is also abundant and active below the Antarctic shelf ice ${ }^{93}$ and might participate in sulfur cycling ${ }^{111}$, including DMSP from ice algae ${ }^{112}$. Increasing loss of sea ice might therefore diminish the recycling of inorganic substrates.

\section{Spring and summer}

\section{Microbial succession in the WSC}

Once daylight reached $\sim 20 \mathrm{~h}$ in mid-April, the microbial system quickly returned to a phototrophic state. The winter-spring transition occurred within two weeks and hence as rapid as in warmer Pacific waters ${ }^{113}$, emphasizing light as the fundamental trigger. Eukaryotic composition changed ahead of bacterial communitieswhereas heterotrophs responded with delay of approximately 14 days to the prime photosynthetic peak (Extended Data Fig. 6). We observed 
three distinct bloom stages, featuring phototrophic pioneers (Phaeocystis and Chaetoceros) followed by araphid-pennate diatoms (Grammonema) and centric diatoms (Thalassiosira). A comparable three-stage summer bloom in the preceding year in nearby Kongsfjorden ${ }^{21}$ suggests recurrent principles in the ice-free Fram Strait. The swift replacement of eukaryotic heterotrophs by photoautotrophs (Fig. 3b, Extended Data Fig. 6) suggests considerable energy fluxes around the winter-spring transition, corresponding to transparent exopolymer particles ${ }^{36}$ and sinking radiolarians ${ }^{114}$, with effects on zooplankton grazing and deep-water biology ${ }^{115,116}$. The two early bacterial responders Aurantivirga and SAR92 (Extended Data Fig. 6) also appeared first in the Antarctic spring bloom ${ }^{22}$, indicating comparable ecological roles. The Grammonema abundance of $>50 \%$ in May coincided with peaking chlorophyll (Fig. 6a), indicating substantial biomass and release of carbohydrates ${ }^{117}$. In this context, intermittent peaks of Formosa, Polaribacter and NS clades (Fig. 6a) illustrate carbohydrate-driven niches, resembling diatom-flavobacteria relationships in temperate and Antarctic waters ${ }^{51,118-120}$.

Thalassiosira was specific for summer and the final bloom stage, when nitrate and phosphate started declining and oxygen concentrations were highest (Fig. 6). The relative increase of mixotrophic flagellates (e.g. Gyrodinium and Woloszynskia) and concurrently decreasing chlorophyll indicates a shifting trophic structure, with probable effects on zooplankton activities ${ }^{121-}$ 123. Increase of the roseobacter Amylibacter (formerly NAC11-7) to 15\% relative abundance emphasized the beginning transition to the autumn post-bloom where Rhodobacteraceae dominated (Fig. 4). Accordingly, the final sampling event in July 2017 clustered with August 2016 but not with the other summer samples (Fig. 3a). We hypothesize concurrent generation of detritus particles, given the typical termination of diatom blooms by aggregation ${ }^{64,124}$ and the association of Amylibacter with related particles ${ }^{125}$. Furthermore, the appearance of suctorian ciliates (Ephelota) and ectoparasitoid dinoflagellates (Chytriodinium) indicates the start of parasitism on diatoms and larger metazoans ${ }^{126,127}$.

Absence of major phototrophic peaks in the EGC

Sequence abundances of Phaeocystis only reached $9 \%$ compared to $40 \%$ in the WSC, presumably forming an under-ice bloom ${ }^{30}$ as ice cover was $\sim 90 \%$ at this time (Fig. 1b). Diatom abundances resembled those during winter (Extended Data Fig. 5), and chlorophyll concentrations were threefold lower than the WSC peak (Fig. 6b). Fragilariopsis and Chaetoceros together only constituted $<10 \%$ of eukaryotic sequences, although nutrients were not limiting (Fig. 6b, Supplementary Table S2). Instead, Syndiniales prevailed over summer, with additional peaks of heterotrophic stramenopile and TAGIRI lineages (Figs. 4, 6a). The flagellates Chromidina (Ciliophora: Opalinopsidae) and Gyrodinium (Dinoflagellata: Gymnodiniaceae) 
constituted between 13 and 35\% of eukaryote sequences depending on ice cover. Chromidina was specific to spring and is normally considered as animal parasite, suggesting yet undescribed niches in the marginal ice zone potentially related to the concurrent occurrence of amphipods ${ }^{128}$.

The lower extent of primary production coincided with lower flavobacterial abundances compared to the WSC (Figs. 2a, 4b), including delayed appearance of the typical phytoplankton associates OCS116, Lentimonas and Luteolibacter ${ }^{129,130}$ (Fig. 6a). Peaks of gammaproteobacterial Oceanospirillales (Nitrincolaceae, Marinomonas) and an EGC-specific Cryomorphaceae lineage (Fig. 6a) supported the notion of a different food web based on other substrates. The presence of ice cover over summer suggests a continuous input of ice-derived substrates. These likely fueled the major peak of Colwellia, which can rapidly and efficiently grow on both high- and low-molecular weight organic matter from sea ice ${ }^{69}$.

\section{ECOLOGICAL CONCLUSIONS}

Our comprehensive analysis of microbial seasonality in the Fram Strait by autonomous yearround sampling identified marked seasonal contrasts, distinct transition events, and short-term dynamics during mixing events and other environmental fluctuations ${ }^{11}$. The characterization of bloom stages, ephemeral abundance peaks and polar night characteristics promotes the understanding of the drivers and timescales of microbial seasonality in ice-covered and ice-free waters. These insights yield a number of fundamental ecological conclusions, with implications for the current and future Arctic Ocean.

1. We identified major principles of seasonality in the Arctic Ocean, with different levels of variability: (i) marked seasonal contrasts especially in the ice-free WSC; (ii) month-to-month dynamics following temperature and stratification gradients in the WSC; and (iii) ephemeral peaks related to diatom-flavobacterial relationships (WSC) or to intermittent changes in ice cover and hydrography (EGC).

2. Dynamics in the WSC represent key principles of seasonality in the ice-free, pelagic Arctic Ocean: Phaeocystis as daylight pioneer followed by araphid-pennate diatoms and maximum chlorophyll (spring); declining nitrate and concurrent shift towards mixotrophic flagellates and centric diatoms (summer); minimum nutrients and highest temperatures when Coscinodiscophyceae diatoms and oligotrophic bacteria prevailed (autumn); and heterotrophic microbial recyclers and nutrient replenishment during vertical mixing (winter). Comparable observations have been made in a year-round study using Niskin-based sampling ${ }^{19}$, illustrating that autonomous techniques provide results consistent with traditional approaches while considerably increasing temporal resolution. The present study has 
remarkable similarities to a RAS-based study in the open Southern Ocean, which reports Coscinodiscophyceae in autumn, Aurantivirga and SAR92 as first bacterial responders, and Amylibacter at the summer-autumn transition ${ }^{22}$. This suggests fundamental "bi-polar" patterns of microbial seasonality, only discernable by autonomous sampling.

3. The EGC mooring served to analyze dynamic effects of the extent of ice cover: it (i) extended the duration and abundance of winter taxa such as SAR406 and Colwellia when ice remained high in summer, (ii) light-limited phytoplankton growth, which only increased at low ice in autumn, and (iii) sustained a distinct heterotrophic signature throughout the year. Increasing light availability at low ice cover favored Phaeocystis, Thalassiosira, OCS116 and Aurantivirga (Extended Data Fig. 7b). These dynamics are sentinels of how the future EGC might shift from an ice-controlled to a light-controlled habitat ${ }^{34,131}$; affecting the fate of blooms ${ }^{132-134}$, the quality and quantity of algae-derived organic matter ${ }^{135}$, and the biological carbon pump ${ }^{136}$. Elevated photosynthesis and higher organic load might stimulate the microbial loop ${ }^{137,138}$, with rapid remineralization of ice-derived organic matter $25,139,140$ at the expense of autotrophic sulfur and nitrogen metabolism ${ }^{111,141}$.

4. Atlantification of the Arctic may enhance early blooms of Phaeocystis ${ }^{30,33,142}$ and substantially alter biogeochemical fluxes, considering the associated production of TEP that serves as microbial substrate, microhabitat and downward vehicle of organic matter. If stratification becomes stronger and more permanent with increasing temperatures, wintertime convection could diminish and deep-water "recycling taxa" disappear from the winter assemblage, with yet unknown ecological consequences.

In conclusion, the demonstrated seasonal dynamics and drivers of Arctic Ocean microbiomes are essential to understanding ecosystem functioning over polar day and night. Considering the anticipated impact of climate change on polar regions and the relevance of microbes in future ocean scenarios ${ }^{1,2}$, our evidence contributes to assessing natural variability, anthropogenic impact and microbial dynamics of the warming Arctic Ocean.

\section{MATERIALS AND METHODS}

Sampling approach. Within the framework of the FRAM long-term marine observatory (https://www.awi.de/en/expedition/observatories/ocean-fram.html), Remote Access Samplers (McLane, East Falmouth, MA) were deployed in July 2016 on seafloor moorings F4-S-1 in the core WSC (79.0118N 6.9648E) and EGC-3 in the marginal ice zone (78.831 N -2.7938E) at 20 and $80 \mathrm{~m}$ depth respectively (Fig. 1a). The fixed-point (Eulerian) approach, established standard in biological time-series observations, includes variation relating to the continuous movement of 
water masses. These also moved the RAS up and down in the water column, resulting in variable actual sampling depths (on average $40 \mathrm{~m}$ for F4-S-1 and $90 \mathrm{~m}$ for EGC-3; Supplementary Table S1). RAS frames were equipped with 48 sterile sampling bags, each containing $700 \mu \mathrm{L}$ saturated mercuric chloride solution. At each programmed sampling event, two water samples of $500 \mathrm{~mL}$ were autonomously pumped an hour apart into individual sampling bags and fixed by the mixing with mercuric chloride. RAS were recovered in August 2017 and water samples immediately filtered through $0.22 \mu \mathrm{m}$ Sterivex filter cartridges (Millipore, Burlington, MA). Filters were frozen at $-20^{\circ} \mathrm{C}$ until DNA extraction in the home lab.

DNA extraction and amplicon sequencing. DNA was extracted using the PowerWater kit (QIAGEN, Germany) according to the manufacturer's instructions, and quantified using Quantus (Promega, Madison, WI). Microbial 16S and 18S rRNA gene fragments were amplified using primers $515 \mathrm{~F}-926 \mathrm{R}^{143}$ and $528 \mathrm{iF}-964 \mathrm{iR}^{38}$ respectively. Libraries were prepared according to the 16S Metagenomic Sequencing Library Preparation protocol (Illumina, San Diego, CA). 16S and 18S rRNA gene fragments were sequenced using MiSeq technology at CeBiTec (Bielefeld, Germany) or Alfred Wegener Institute respectively (Supplementary Methods).

Sequence analysis. After primer removal using cutadapt ${ }^{144}$ reads were processed into amplicon sequence variants (ASVs) using DADA2 v1.14.1145. For $16 \mathrm{~S}$ amplicons, reads from two independent Illumina runs were merged after error learning as per the author's recommendation. Reads were quality-trimmed based on DADA quality profiles. After singleton removal, we obtained on average 62,000 16S rRNA and 99,000 18S rRNA reads per sample (Supplementary Table S3) that sufficiently covered community composition (Extended Data Fig. 8). Prokaryotic and eukaryotic reads were taxonomically classified using Silva v138 and PR ${ }^{2}$ v4.12 databases respectively (Supplementary Methods). Subsequently, two samples collected at $>200 \mathrm{~m}$ depth were discarded to omit potential deep-water signatures.

Mooring and satellite data. Temperature, salinity, oxygen concentration and oxygen saturation were derived from a CTD sensor attached next to the RAS, confirming consistent properties of the two water samples from each date. The physical sensors were manufacturer-calibrated and processed in accordance with https://epic.awi.de/id/eprint/43137. Raw and processed mooring data are available $\mathrm{at}^{146}$. For chemical sensors, the raw sensor readouts are reported. Partial $\mathrm{CO}_{2}$ pressure and $\mathrm{pH}$ were measured in the WSC only. Water masses and the fraction of Atlantic and Polar Water were characterized following Richter and colleagues ${ }^{147}$ at each sampling event (Supplementary Methods). Sea ice concentrations derived from the Advanced Microwave Scanning Radiometer sensor AMSR-2 ${ }^{148}$ were downloaded from Institute of Environmental Physics, University of Bremen (https://seaice.uni-bremen.de/sea-ice-concentration-amsr- 
eamsr2). Surface chlorophyll concentrations measured with the Sentinel 3A OLCl were downloaded from https://earth.esa.int/web/sentinel/sentinel-data-access. For all satellite-derived data, we considered grid points within a radius of $15 \mathrm{~km}$ around the moorings.

Nutrient quantification. Analyses were done using a QuAAtro Seal Analytical segmented continuous flow autoanalyser following standard colorimetric techniques. The accuracy of the analysis was evaluated using KANSO LTD Japan Certified Reference Materials, with corrections applied as required. After quality control in comparison with reference data, samples with QC score $\geq 4$ were excluded from further analyses (labelled NA in Supplementary Table S1).

Statistical evaluation. Data analysis was done in $\mathrm{R}$ v3.6.1 $1^{149}$ implemented in RStudio (https://rstudio.com). In short, alpha-diversity (inverse Simpson index) and rarefaction curves were computed on raw ASV counts, excluding metazoan, chloroplast and mitochondrial sequences. Subsequently, we only considered reads with $\geq 3$ counts in $\geq 2$ samples. NMDS was performed using Jenson-Shannon distances on Hellinger-transformed ASV counts. Seasons were defined based on multivariate patterning of oceanographic parameters and microbial community composition (Figs. 2-3). Water masses were categorized as AW or PW at proportions of $>80 \%$ respectively; and $20-80 \%$ as mixture of both. Statistical differences were computed by PERMANOVA, Wilcoxon rank-sum test, or Kruskal-Wallis plus Bonferroni-corrected Dunn's posthoc test whenever appropriate. Pairwise associations were assessed by Spearman's correlation coefficients.

Data availability. Amplicon sequences have been deposited in the European Nucleotide Archive under accession numbers PRJEB43890 (16S) and PRJEB43504 (18S) using the data brokerage service of the German Federation for Biological Data (GFBio) in compliance with MIxS standards. Environmental data has been deposited at PANGAEA (see Supplementary Table S1). Code and input files for reproducing workflow and figures are available at https://github.com/matthiaswietz/RAS-1617.

\section{Acknowledgements}

We thank Jana Bäger, Theresa Hargesheimer, Daniel Scholz, Rafael Stiens and Lili Hufnagel for RAS operation; Normen Lochthofen, Janine Ludszuweit, Lennard Frommhold and Jonas Hagemann for mooring operation; Jakob Barz and Swantje Rogge for DNA extraction and library preparation; Halina Tegetmeyer for quality-control and sequencing of 16S rRNA amplicons; and Laura Wischnewski for nutrient analysis. Christiane Hassenrück, Stefan Neuhaus, Pier L. Buttigieg, Magda Cardozo and Andrew B. Collier contributed bioinformatic assistance. We thank Eva-Maria Nöthig for constructive discussions and the entire FRAM team for excellent 
collaboration at home and sea. The captain, crew and scientists of RV Polarstern cruises PS99 and PS107 are gratefully acknowledged. Ship time was provided under grants AWI_PS99_00 and AWI_PS107_05. This project has received funding from the European Research Council (ERC) under the European Union's Seventh Framework Program (FP7/2007-2013) research project ABYSS (Grant Agreement no. 294757) to AB. Additional funding came from the Helmholtz Association, specifically for the FRAM infrastructure and from the Max Planck Society. This publication is Eprint ID XXXXX of the Alfred Wegener Institute Helmholtz Center for Polar and Marine Research, Bremerhaven, Germany.

\section{FIGURES}
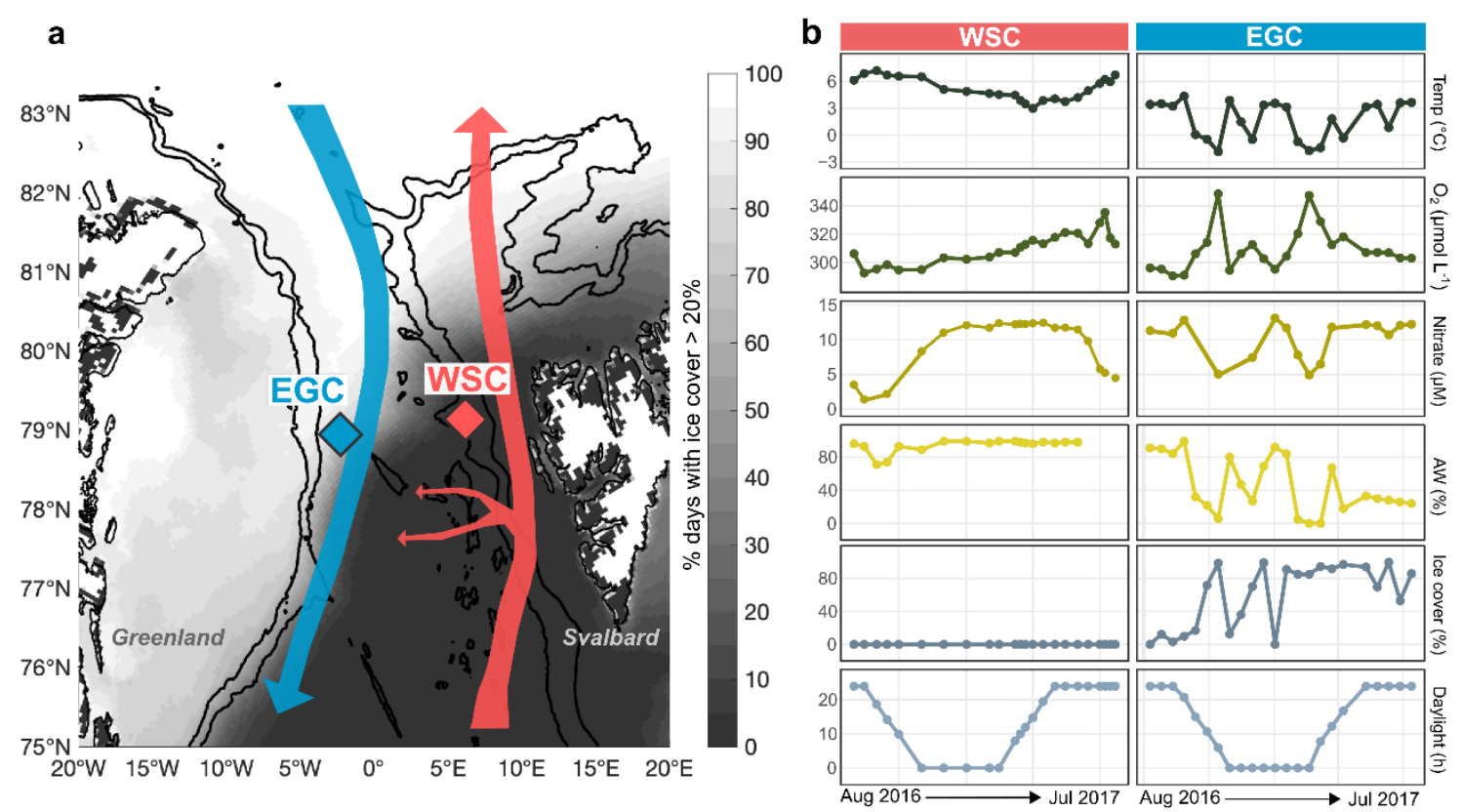

Fig. 1 - Study area and oceanographic conditions. a: Location of moored Remote Access Samplers in the East Greenland Current (EGC) and the West Spitsbergen Current (WSC) of Fram Strait, indicated in blue and red respectively. The small red arrows illustrate recirculation of Atlantic Water in central Fram Strait. The grayscale gradient illustrates the percentage of days with average ice cover of $>20 \%$. b: Annual water temperature $\left({ }^{\circ} \mathrm{C}\right)$, concentrations of oxygen $\left(\mu \mathrm{mol} \mathrm{L} \mathrm{L}^{-1}\right)$ and nitrate $(\mu \mathrm{M})$, the proportion of Atlantic Water (\%), sea ice cover (\%), and daylight hours. 


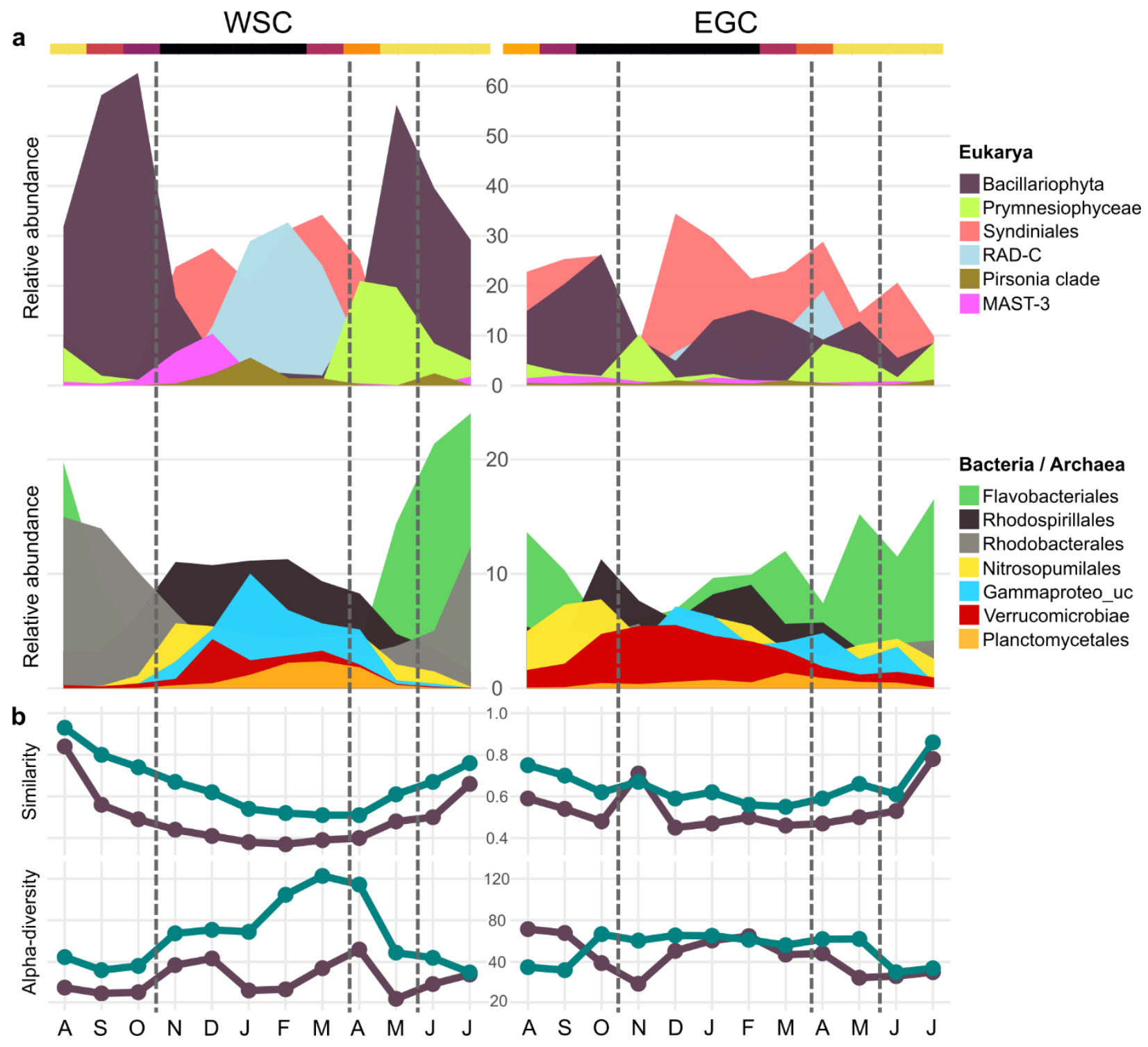

Fig. 2 - Annual cycle of microbial community structure and turnover. a: Relative sequence abundances (\%) of eukaryotic, bacterial and archaeal taxa over the annual cycle. b, upper panel: Microbial community turnover (taxonomic similarities expressed as 1-Jenson-Shannon distance) compared to the first sampling event. b, lower panel: Microbial alpha-diversity (inverse Simpson index). Eukaryotes: purple; bacteria and archaea: green. Lines indicate the seasonal boundaries defined by multivariate evaluation of physicochemical and microbial dynamics (Fig. 3). 


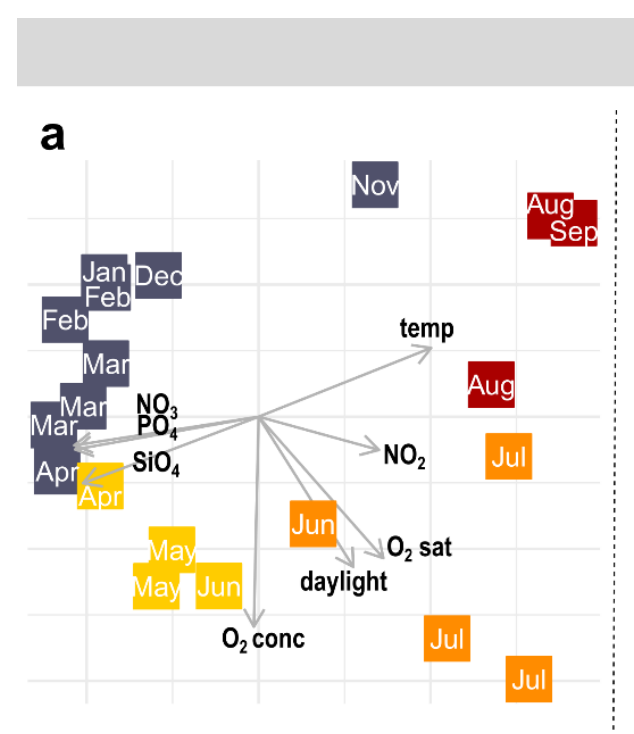

\section{WSC}

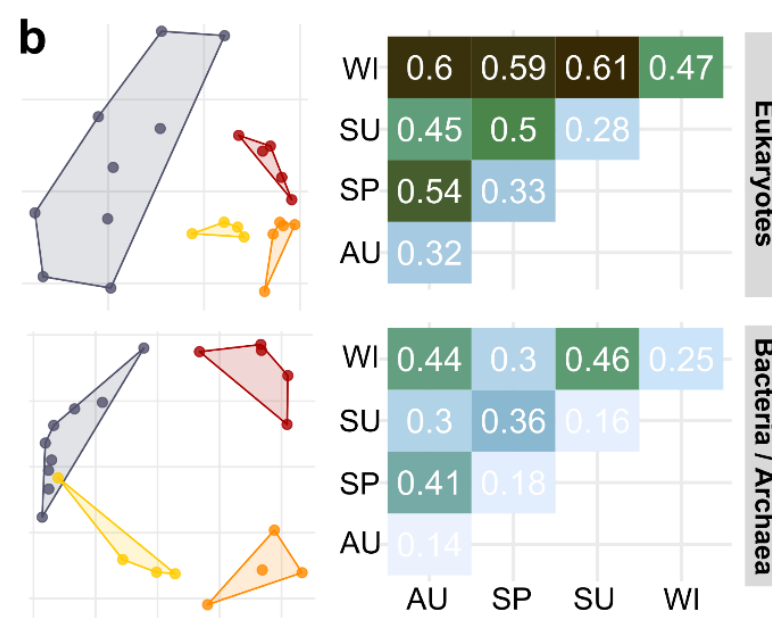

\section{EGC}
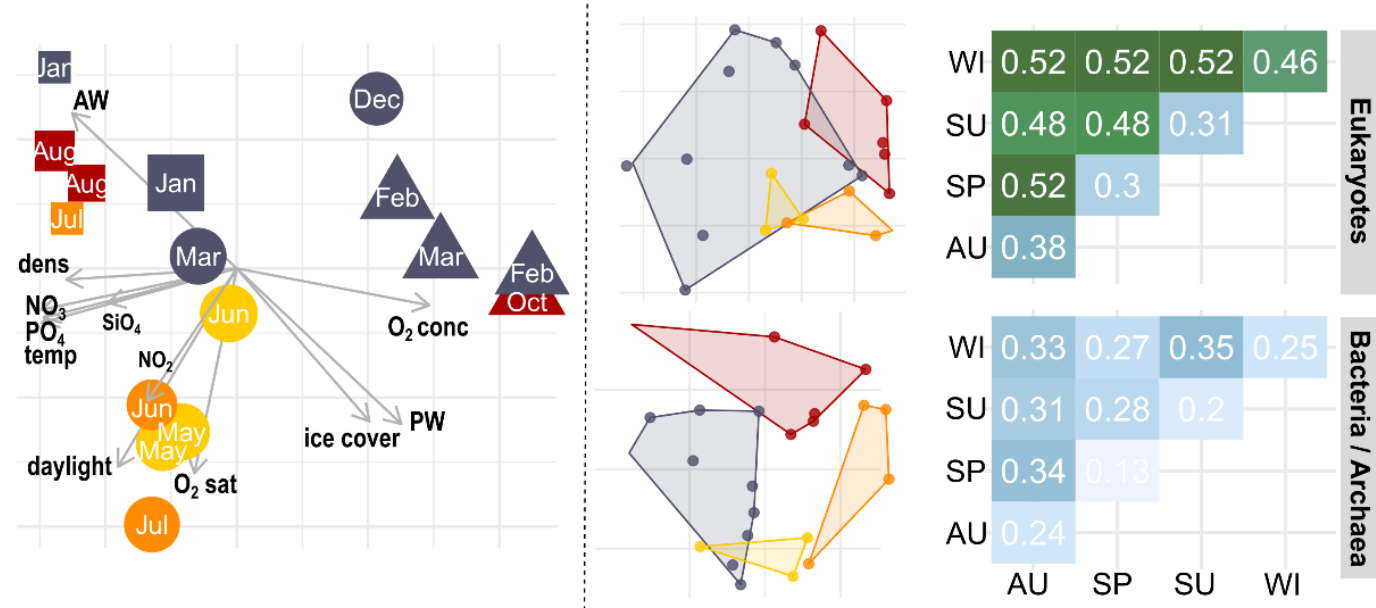

Water mass

$\square$ AW

$\triangle P W$

$\bigcirc$ mix
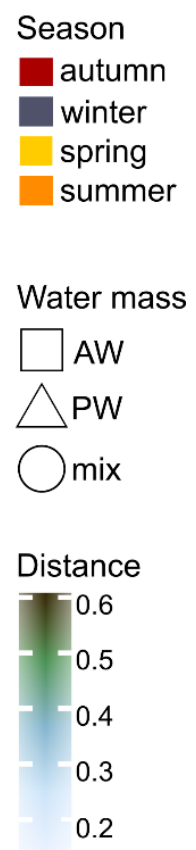

Fig. 3 - Microbial and environmental seasonality. a: Principal Component Analysis of environmental conditions. Components 1 and 2 explained 58/26\% (WSC) and 60/14\% (EGC), respectively, and hence the majority of physicochemical seasonality. For EGC, label size indicates percent ice cover. Only sampling events with complete environmental data were considered. b: Non-metric multidimensional scaling of Hellinger-transformed relative ASV abundances (stress values $0.06,0.03,0.12,0.1$ respectively) and corresponding JensenShannon distances between and within seasons (larger numbers designating more dissimilar communities). 


\section{WSC EGC}

a

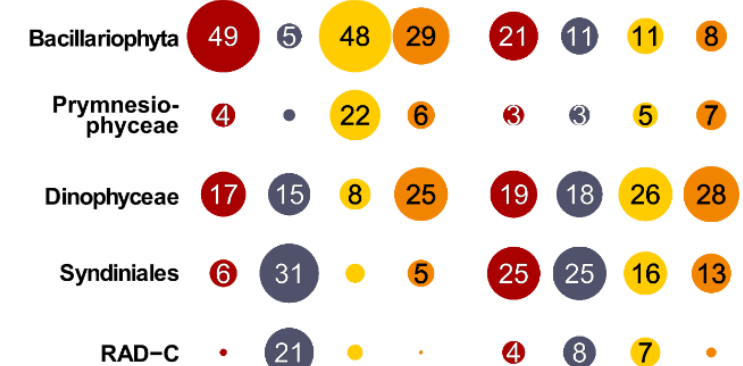

b Raphid-pennate
Mediophyceae

Phaeocystaceae

Araphid-pennate

Mamiellaceae

Gymnodiniaceae

Strombididae M

Chytriodiniaceae

Tovelliaceae

Pelagophyceae

Suessiaceae

Coscinodiscophyceae

Ceratiaceae

Heterocapsaceae

Pelagomonadaceae

Opalinopsidae

Syndiniales (Group I-1)

Syndiniales (Group II-7)

RAD-C

RAD-B-Group-IV

MAST-3I

Pirsonia clade
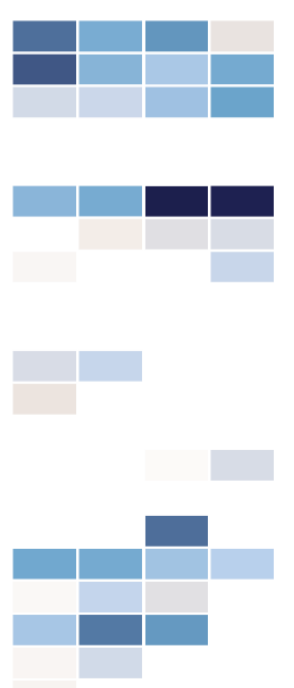

WSC

$\begin{gathered}\text { Alphaproteo- } \\ \text { bacteria }\end{gathered} 57,42 \quad 39 \quad 46$

Gammaproteo-

bacteria

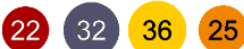

$14 \quad 4 \quad 14 \quad 25$

Bacteroidia

Nitroso-

sphaeria

Verruco-

microbiae

SAR11 Clade I SAR86 clade

Thioglobaceae

Nitrincolaceae

Flavobacteriaceae

Cryomorphaceae

OcS116 clade

Rhodobacteraceae

SAR116 clade

AEGEAN-169

Magnetospiraceae

Defluviicoccales_uc

Nitrosopumilaceae

Dadabacteriales

Arctic97B-4

Rubritaleaceae

Nitrospinaceae

Pirellulaceae

Gammaproteo_uc

Woeseiaceae

Colwelliaceae SAR406

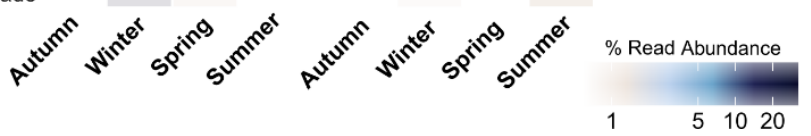

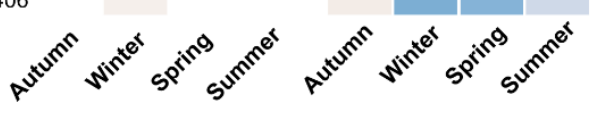

Fig. 4 - Microbes as indicators for seasons. Relative sequence abundances of major microbial classes (a) and families (b) by season. For classes only sequence abundances $>3 \%$ are shown. 


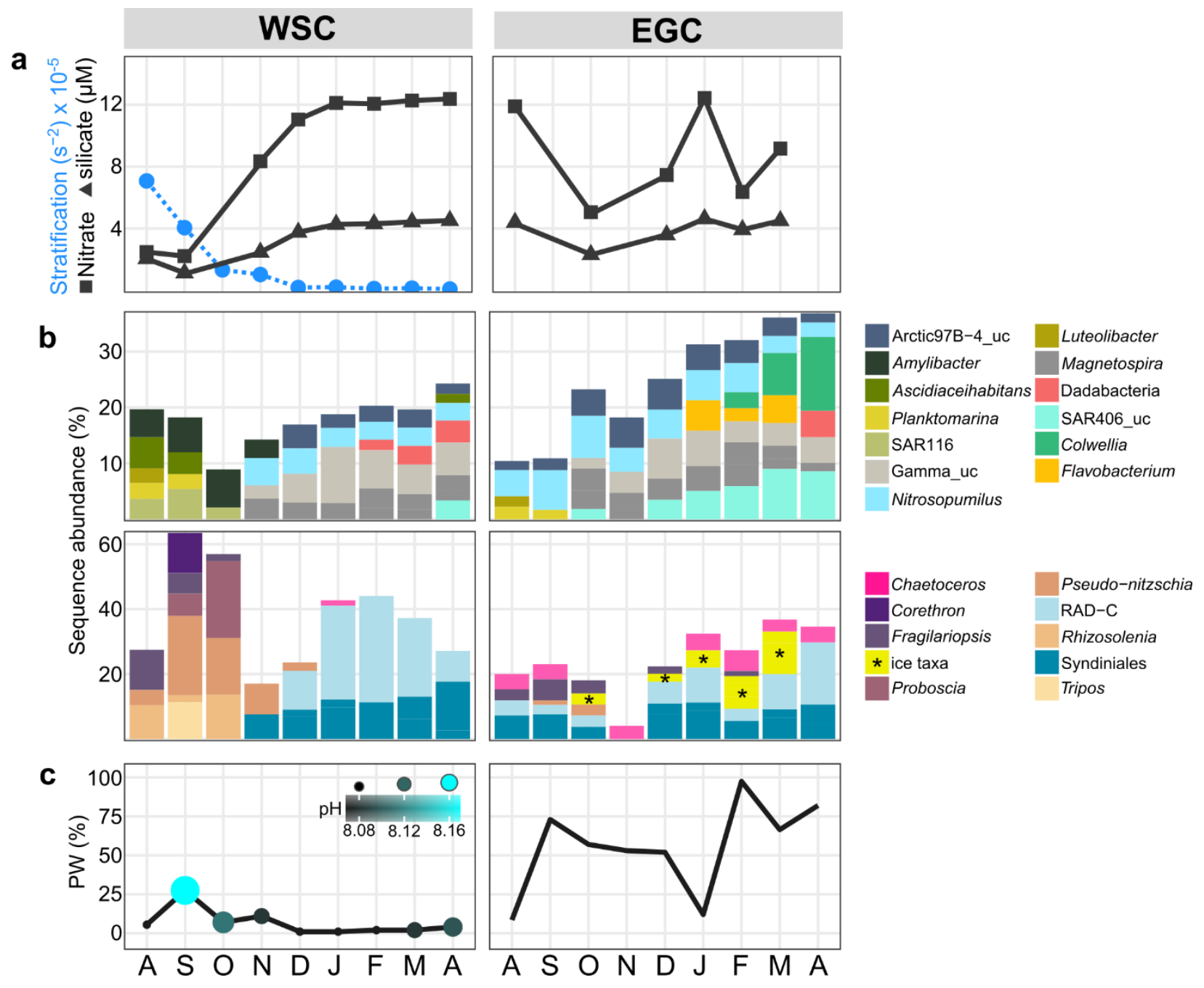

Fig. 5 - Autumn and winter. a: Concentrations of nitrate (squares) and silicate (triangles) in relation to stratification (blue; only available for the WSC). b: Microbial genera with increased proportions in autumn or winter. "Winter-ice" eukaryotes are combined (marked with asterisks; see Extended Data Fig. 7a for abundances of each genus). c: $\mathrm{pH}$ values (only available for the WSC) and proportions of PW. 


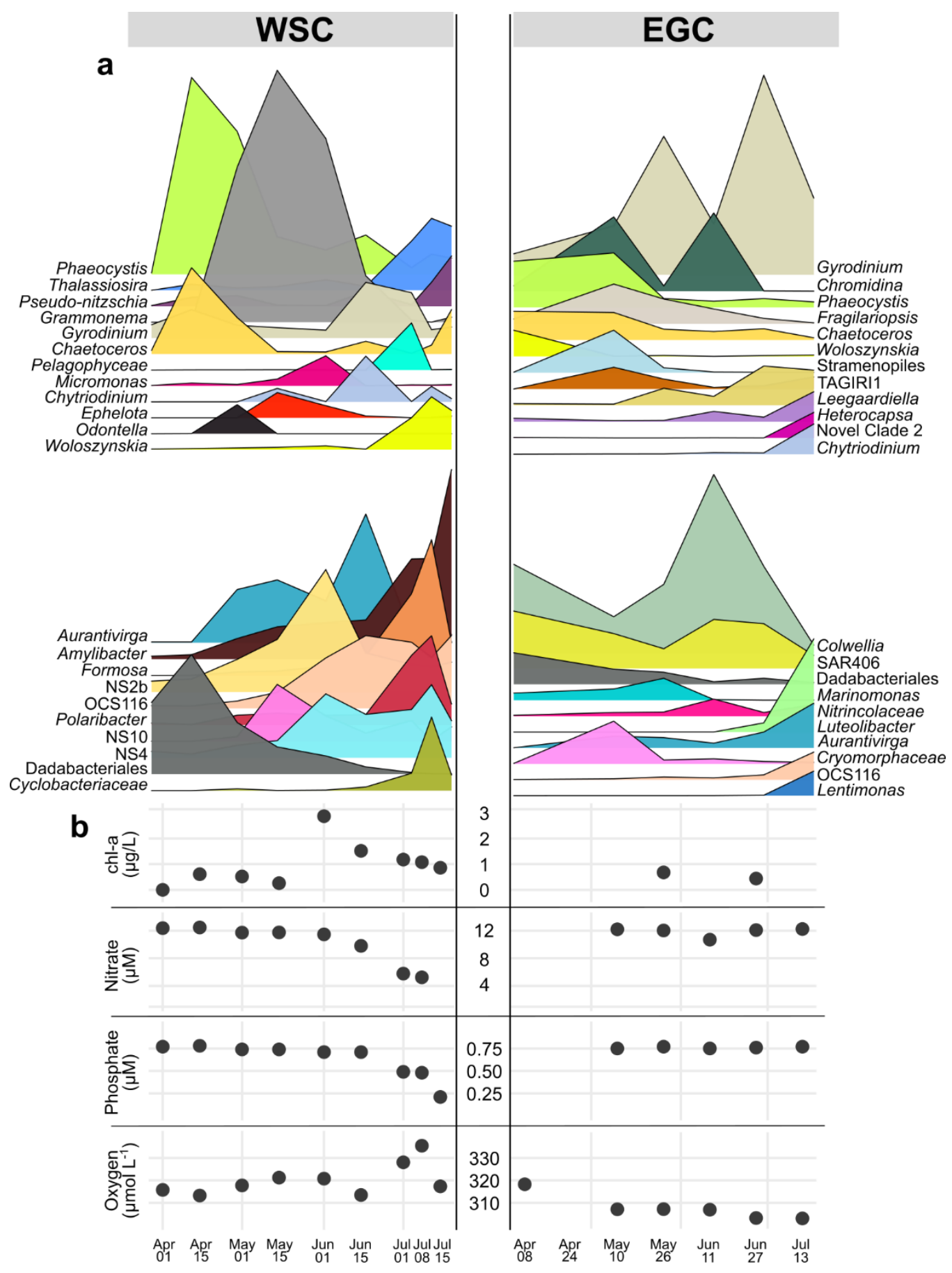

Fig. 6 - Spring and summer. a: Relative abundances of dominant eukaryotic and bacterial genera. b: Concentrations of chlorophyll, nitrate, phosphate and oxygen. 


\section{REFERENCES}

1. Cavicchioli, R. et al. Scientists' warning to humanity: microorganisms and climate change. Nat. Rev. Microbiol. 17, 569-586 (2019).

2. Pachauri, R. K. et al. Climate Change 2014: Synthesis Report. Contribution of Working Groups I, II and III to the Fifth Assessment Report of the Intergovernmental Panel on Climate Change. (2014).

3. Bunse, C. \& Pinhassi, J. Marine Bacterioplankton Seasonal Succession Dynamics. Trends Microbiol. 25, 494-505 (2017).

4. Buttigieg, P. L. et al. Marine microbes in 4D-using time series observation to assess the dynamics of the ocean microbiome and its links to ocean health. Curr. Opin. Microbiol. 43, 169-185 (2018).

5. Gilbert, J. A. et al. Defining seasonal marine microbial community dynamics. ISME J. 6, 298308 (2012).

6. Cram, J. A. et al. Seasonal and interannual variability of the marine bacterioplankton community throughout the water column over ten years. ISME J. 9, 563-580 (2015).

7. Lindh, M. V. et al. Disentangling seasonal bacterioplankton population dynamics by highfrequency sampling. Environ. Microbiol. 17, 2459-2476 (2015).

8. Needham, D. M. \& Fuhrman, J. A. Pronounced daily succession of phytoplankton, archaea and bacteria following a spring bloom. Nat. Microbiol. 1, 16005 (2016).

9. Ward, C. S. et al. Annual community patterns are driven by seasonal switching between closely related marine bacteria. ISME J. 11, 1412-1422 (2017).

10. Martin-Platero, A. M. et al. High resolution time series reveals cohesive but short-lived communities in coastal plankton. Nat. Commun. 9, 266 (2018).

11. Needham, D. M. et al. Dynamics and interactions of highly resolved marine plankton via automated high-frequency sampling. ISME J. 12, 2417-2432 (2018).

12. Bunse, C. et al. High Frequency Multi-Year Variability in Baltic Sea Microbial Plankton Stocks and Activities. Front. Microbiol. 9, (2019).

13. Banos, S. et al. Seasonal Dynamics of Pelagic Mycoplanktonic Communities: Interplay of Taxon Abundance, Temporal Occurrence, and Biotic Interactions. Front. Microbiol. 11, (2020).

14. Sherr, E. B., Sherr, B. F., Wheeler, P. A. \& Thompson, K. Temporal and spatial variation in stocks of autotrophic and heterotrophic microbes in the upper water column of the central Arctic Ocean. Deep Sea Res. Part Oceanogr. Res. Pap. 50, 557-571 (2003). 
15. Alonso-Saez, L., Sanchez, O., Gasol, J. M., Balague, V. \& Pedros-Alio, C. Winter-to-summer changes in the composition and single-cell activity of near-surface Arctic prokaryotes. Environ. Microbiol. 10, 2444-54 (2008).

16. Rokkan Iversen, K. \& Seuthe, L. Seasonal microbial processes in a high-latitude fjord (Kongsfjorden, Svalbard): I. Heterotrophic bacteria, picoplankton and nanoflagellates. Polar Biol. 34, 731-749 (2011).

17. Pedrós-Alió, C., Potvin, M. \& Lovejoy, C. Diversity of planktonic microorganisms in the Arctic Ocean. Prog. Oceanogr. 139, 233-243 (2015).

18. Marquardt, M., Vader, A., Stubner, E. I., Reigstad, M. \& Gabrielsen, T. M. Strong Seasonality of Marine Microbial Eukaryotes in a High-Arctic Fjord (Isfjorden, in West Spitsbergen, Norway). Appl. Environ. Microbiol. 82, 1868-1880 (2016).

19. Wilson, B. et al. Changes in Marine Prokaryote Composition with Season and Depth Over an Arctic Polar Year. Front. Mar. Sci. 4, 95 (2017).

20. Sandaa, R.-A. et al. Seasonality Drives Microbial Community Structure, Shaping both Eukaryotic and Prokaryotic Host ${ }^{-}$Viral Relationships in an Arctic Marine Ecosystem. Viruses 10, 715 (2018).

21. Singh, A., Divya, D. T., Tripathy, S. C. \& Naik, R. K. Interplay of regional oceanography and biogeochemistry on phytoplankton bloom development in an Arctic fjord. Estuar. Coast. Shelf Sci. 106916 (2020) doi:10.1016/j.ecss.2020.106916.

22. Liu, Y., Blain, S., Crispi, O., Rembauville, M. \& Obernosterer, I. Seasonal dynamics of prokaryotes and their associations with diatoms in the Southern Ocean as revealed by an autonomous sampler. Environ. Microbiol. 22, 3968-3984 (2020).

23. Randelhoff, A. et al. Arctic mid-winter phytoplankton growth revealed by autonomous profilers. Sci. Adv. 6, eabc2678 (2020).

24. Randelhoff, A., Sundfjord, A. \& Reigstad, M. Seasonal variability and fluxes of nitrate in the surface waters over the Arctic shelf slope. Geophys. Res. Lett. 42, 3442-3449 (2015).

25. Randelhoff, A. et al. Seasonality of the Physical and Biogeochemical Hydrography in the Inflow to the Arctic Ocean Through Fram Strait. Front. Mar. Sci. 5, (2018).

26. Berge, J. et al. In the dark: A review of ecosystem processes during the Arctic polar night. Prog. Oceanogr. 139, 258-271 (2015).

27. Müller, O. et al. Spatiotemporal Dynamics of Ammonia-Oxidizing Thaumarchaeota in Distinct Arctic Water Masses. Front. Microbiol. 9, (2018). 
28. Johnsen, G., Leu, E. \& Gradinger, R. Marine Micro- and Macroalgae in the Polar Night. in Polar Night Marine Ecology: Life and Light in the Dead of Night (eds. Berge, J., Johnsen, G. \& Cohen, J. H.) 67-112 (Springer International Publishing, 2020)..

29. Vader, A., Marquardt, M., Meshram, A. \& Gabrielsen, T. Key Arctic phototrophs are widespread in the polar night. Polar Biol. 38, 13-21 (2014).

30. Assmy, P. et al. Leads in Arctic pack ice enable early phytoplankton blooms below snowcovered sea ice. Sci. Rep. 7, 40850 (2017).

31. Soltwedel, T. et al. Natural variability or anthropogenically-induced variation? Insights from 15 years of multidisciplinary observations at the arctic marine LTER site HAUSGARTEN. Ecol. Indic. 65, 89-102 (2016).

32. Nöthig, E.-M. et al. Summertime Chlorophyll a and Particulate Organic Carbon Standing Stocks in Surface Waters of the Fram Strait and the Arctic Ocean (1991-2015). Front. Mar. Sci. 7, (2020).

33. Nöthig, E.-M. et al. Summertime plankton ecology in Fram Strait-a compilation of long- and short-term observations. Polar Res. 34, 23349 (2015).

34. Metfies, K., von Appen, W.-J., Kilias, E., Nicolaus, A. \& Nöthig, E.-M. Biogeography and Photosynthetic Biomass of Arctic Marine Pico-Eukaroytes during Summer of the Record Sea Ice Minimum 2012. PLOS ONE 11, e0148512-e0148512 (2016).

35. Metfies, K. et al. Protist Communities in Moored Long-Term Sediment Traps (Fram Strait, Arctic)-Preservation with Mercury Chloride Allows for PCR-Based Molecular Genetic Analyses. Front. Mar. Sci. 4, (2017).

36. Engel, A. et al. Inter-annual variability of transparent exopolymer particles in the Arctic Ocean reveals high sensitivity to ecosystem changes. Sci. Rep. 7, 4129 (2017).

37. Engel, A. et al. Inter-Annual Variability of Organic Carbon Concentration in the Eastern Fram Strait During Summer (2009-2017). Front. Mar. Sci. 6, (2019).

38. Fadeev, E. et al. Microbial Communities in the East and West Fram Strait During Sea Ice Melting Season. Front. Mar. Sci. 5, (2018).

39. von Jackowski, A., Grosse, J., Nöthig, E.-M. \& Engel, A. Dynamics of organic matter and bacterial activity in the Fram Strait during summer and autumn. Philos. Trans. R. Soc. Math. Phys. Eng. Sci. 378, 20190366 (2020).

40. Polyakov, I. V. et al. Greater role for Atlantic inflows on sea-ice loss in the Eurasian Basin of the Arctic Ocean. Science 356, 285 (2017).

41. Wassmann, P., Slagstad, D. \& Ellingsen, I. Advection of Mesozooplankton Into the Northern Svalbard Shelf Region. Front. Mar. Sci. 6, (2019). 
42. Arrigo, K. R. \& van Dijken, G. L. Continued increases in Arctic Ocean primary production. Prog. Oceanogr. 136, 60-70 (2015).

43. Schröter, F. et al. Pelagic Amphipods in the Eastern Fram Strait With Continuing Presence of Themisto compressa Based on Sediment Trap Time Series. Front. Mar. Sci. 6, (2019).

44. Lannuzel, D. et al. The future of Arctic sea-ice biogeochemistry and ice-associated ecosystems. Nat. Clim. Change 1-10 (2020).

45. Carter-Gates, M. et al. Implications of increasing Atlantic influence for Arctic microbial community structure. Sci. Rep. 10, 19262 (2020).

46. von Appen, W.-J., Schauer, U., Hattermann, T. \& Beszczynska-Möller, A. Seasonal Cycle of Mesoscale Instability of the West Spitsbergen Current. J. Phys. Oceanogr. 46, 1231-1254 (2016).

47. Wekerle, C. et al. Eddy-Resolving Simulation of the Atlantic Water Circulation in the Fram Strait With Focus on the Seasonal Cycle. J. Geophys. Res. Oceans 122, 8385-8405 (2017).

48. Giner, C. R. et al. Quantifying long-term recurrence in planktonic microbial eukaryotes. Mol. Ecol. 28, 923-935 (2019).

49. Royo-Llonch, M. et al. Ecogenomics of key prokaryotes in the Arctic Ocean. bioRxiv 2020.06.19.156794 (2020) doi:10.1101/2020.06.19.156794.

50. Sunagawa, S. et al. Structure and function of the global ocean microbiome. Science 348, 1261359 (2015).

51. Teeling, $\mathrm{H}$. et al. Substrate-controlled succession of marine bacterioplankton populations induced by a phytoplankton bloom. Science 336, 608-11 (2012).

52. Scholz, B. et al. Zoosporic parasites infecting marine diatoms - A black box that needs to be opened. Fungal Ecol. 19, 59-76 (2016).

53. Wasmund, N., Göbel, J. \& Bodungen, B. v. 100-years-changes in the phytoplankton community of Kiel Bight (Baltic Sea). J. Mar. Syst. 73, 300-322 (2008).

54. Stoecker, D. K. \& Lavrentyev, P. J. Mixotrophic Plankton in the Polar Seas: A Pan-Arctic Review. Front. Mar. Sci. 5, (2018).

55. Lampe, V., Nöthig, E.-M. \& Schartau, M. Spatio-Temporal Variations in Community Size Structure of Arctic Protist Plankton in the Fram Strait. Front. Mar. Sci. 7, (2021).

56. Brichta, M. \& Nöthig, E.-M. The role of life cycle stages of diatoms in decoupling carbon and silica cycles in polar regions. Oral presentation, SCAR Open Science Conference, 25-31 July, Bremen, Germany. (2004).

57. Not, F. et al. Diversity and Ecology of Eukaryotic Marine Phytoplankton. in Advances in Botanical Research (ed. Piganeau, G.) vol. 64 1-53 (Academic Press, 2012). 
58. Raghukumar, S. Ecology of the marine protists, the Labyrinthulomycetes (Thraustochytrids and Labyrinthulids). Eur. J. Protistol. 38, 127-145 (2002).

59. Kagami, M., Miki, T. \& Takimoto, G. Mycoloop: chytrids in aquatic food webs. Front. Microbiol. 5, (2014).

60. Rapp, J. Z., Fernández-Méndez, M., Bienhold, C. \& Boetius, A. Effects of Ice-Algal Aggregate Export on the Connectivity of Bacterial Communities in the Central Arctic Ocean. Front. Microbiol. 9, (2018).

61. Choi, D. H. et al. Pyrosequencing Revealed SAR116 Clade as Dominant dddP-Containing Bacteria in Oligotrophic NW Pacific Ocean. PLOS ONE 10, e0116271 (2015).

62. Wemheuer, B. et al. The green impact: bacterioplankton response toward a phytoplankton spring bloom in the southern North Sea assessed by comparative metagenomic and metatranscriptomic approaches. Front. Microbiol. 6, (2015).

63. Zeng, Y.-X., Qiao, Z.-Y., Yu, Y., Li, H.-R. \& Luo, W. Diversity of bacterial dimethylsulfoniopropionate degradation genes in surface seawater of Arctic Kongsfjorden. Sci. Rep. 6, 33031 (2016).

64. Alldredge, A. L. \& Gotschalk, C. C. Direct observations of the mass flocculation of diatom blooms: characteristics, settling velocities and formation of diatom aggregates. Deep Sea Res. Part Oceanogr. Res. Pap. 36, 159-171 (1989).

65. Delpech, L.-M. et al. Terrestrial Inputs Shape Coastal Bacterial and Archaeal Communities in a High Arctic Fjord (Isfjorden, Svalbard). Front. Microbiol. 12, (2021).

66. Lundholm, N., Hansen, P. J. \& Kotaki, Y. Effect of $\mathrm{pH}$ on growth and domoic acid production by potentially toxic diatoms of the genera Pseudo-nitzschia and Nitzschia. Mar. Ecol. Prog. Ser. 273, 1-15 (2004).

67. Prince, K. E., Irmer, F. \& Pohnert, G. Domoic Acid Improves the Competitive Ability of Pseudo-nitzschia delicatissima against the Diatom Skeletonema marinoi. Mar. Drugs 11, (2013).

68. Cherkasheva, A. et al. Influence of the physical environment on polar phytoplankton blooms: A case study in the Fram Strait. J. Mar. Syst. 132, 196-207 (2014).

69. Underwood, G. J. C. et al. Organic matter from Arctic sea-ice loss alters bacterial community structure and function. Nat. Clim. Change 9, 170-176 (2019).

70. Graham, E. \& Tully, B. J. Marine Dadabacteria exhibit genome streamlining and phototrophy-driven niche partitioning. bioRxiv (2020).

71. Guillou, L. et al. Widespread occurrence and genetic diversity of marine parasitoids belonging to Syndiniales (Alveolata). Environ. Microbiol. 10, 3349-3365 (2008). 
72. Cleary, A. C. \& Durbin, E. G. Unexpected prevalence of parasite $18 \mathrm{~S}$ rDNA sequences in winter among Antarctic marine protists. J. Plankton Res. 38, 401-417 (2016).

73. Clarke, L. J., Bestley, S., Bissett, A. \& Deagle, B. E. A globally distributed Syndiniales parasite dominates the Southern Ocean micro-eukaryote community near the sea-ice edge. ISME J. 13, 734-737 (2019).

74. García, F. C., Alonso-Sáez, L., Morán, X. A. G. \& López-Urrutia, Á. Seasonality in molecular and cytometric diversity of marine bacterioplankton: the re-shuffling of bacterial taxa by vertical mixing. Environ. Microbiol. 17, 4133-4142 (2015).

75. Hernando-Morales, V. et al. Vertical and Seasonal Patterns Control Bacterioplankton Communities at Two Horizontally Coherent Coastal Upwelling Sites off Galicia (NW Spain). Microb. Ecol. 76, 866-884 (2018).

76. Galand, P. E., Casamayor, E. O., Kirchman, D. L. \& Lovejoy, C. Ecology of the rare microbial biosphere of the Arctic Ocean. Proc. Natl. Acad. Sci. USA 106, 22427-22432 (2009).

77. Jousset, A. et al. Where less may be more: how the rare biosphere pulls ecosystems strings. ISME J. 11, 853-862 (2017).

78. Giner, C. R. et al. Marked changes in diversity and relative activity of picoeukaryotes with depth in the world ocean. ISME J. 14, 437-449 (2020).

79. Lücker, S., Nowka, B., Rattei, T., Spieck, E. \& Daims, H. The Genome of Nitrospina gracilis Illuminates the Metabolism and Evolution of the Major Marine Nitrite Oxidizer. Front. Microbiol. 4, 27 (2013).

80. Lehtovirta-Morley, L. E. Ammonia oxidation: Ecology, physiology, biochemistry and why they must all come together. FEMS Microbiol. Lett. 365, (2018).

81. Reji, L., Tolar, B. B., Smith, J. M., Chavez, F. P. \& Francis, C. A. Differential co-occurrence relationships shaping ecotype diversification within Thaumarchaeota populations in the coastal ocean water column. ISME J. 13, 1144-1158 (2019).

82. Williams, T. J., Lefevre, C. T., Zhao, W., Beveridge, T. J. \& Bazylinski, D. A. Magnetospira thiophila gen. nov., sp. nov., a marine magnetotactic bacterium that represents a novel lineage within the Rhodospirillaceae (Alphaproteobacteria). Int. J. Syst. Evol. Microbiol. 62, 2443-50 (2012).

83. von Friesen, L. W. \& Riemann, L. Nitrogen Fixation in a Changing Arctic Ocean: An Overlooked Source of Nitrogen? Front. Microbiol. 11, (2020).

84. Fernández-Méndez, M. et al. Diazotroph Diversity in the Sea Ice, Melt Ponds, and Surface Waters of the Eurasian Basin of the Central Arctic Ocean. Front Microbiol 7, 1884-1884 (2016). 
85. Williams, T. J. et al. A metaproteomic assessment of winter and summer bacterioplankton from Antarctic Peninsula coastal surface waters. ISME J. 6, 1883-900 (2012).

86. Tolar, B. B. et al. Contribution of ammonia oxidation to chemoautotrophy in Antarctic coastal waters. ISME J. 10, 2605-2619 (2016).

87. Yool, A., Martin, A. P., Fernández, C. \& Clark, D. R. The significance of nitrification for oceanic new production. Nature 447, 999-1002 (2007).

88. Alonso-Saez, L. et al. Role for urea in nitrification by polar marine Archaea. Proc. Natl. Acad. Sci. U. S. A. 109, 17989-94 (2012).

89. Connelly, T. L., Baer, S. E., Cooper, J. T., Bronk, D. A. \& Wawrik, B. Urea uptake and carbon fixation by marine pelagic bacteria and archaea during the Arctic summer and winter seasons. Appl Env. Microbiol 80, 6013-6022 (2014).

90. Gómez-Consarnau, L., Needham, D. M., Weber, P. K., Fuhrman, J. A. \& Mayali, X. Influence of Light on Particulate Organic Matter Utilization by Attached and Free-Living Marine Bacteria. Front. Microbiol. 10, 1204 (2019).

91. Kellogg, C. T. E., McClelland, J. W., Dunton, K. H. \& Crump, B. C. Strong Seasonality in Arctic Estuarine Microbial Food Webs. Front. Microbiol. 10, (2019).

92. Meador, T. B. et al. Carbon recycling efficiency and phosphate turnover by marine nitrifying archaea. Sci. Adv. 6, eaba1799 (2020).

93. Martínez-Pérez, C. et al. Lifting the Lid: Nitrifying Archaea Sustain Diverse Microbial Communities Below the Ross Ice Shelf. Cell (2020) doi:10.2139/ssrn.3677479.

94. Mohamed, N. M., Saito, K., Tal, Y. \& Hill, R. T. Diversity of aerobic and anaerobic ammoniaoxidizing bacteria in marine sponges. ISME J. 4, 38-48 (2010).

95. Mussmann, M., Pjevac, P., Kruger, K. \& Dyksma, S. Genomic repertoire of the Woeseiaceae/JTB255, cosmopolitan and abundant core members of microbial communities in marine sediments. ISME J. 11, 1276-1281 (2017).

96. Burow, L. C., Kong, Y., Nielsen, J. L., Blackall, L. L. \& Nielsen, P. H. Abundance and ecophysiology of Defluviicoccus spp., glycogen-accumulating organisms in full-scale wastewater treatment processes. Microbiology 153, 178-185 (2007).

97. Pfreundt, U., Wambeke, F. V., Caffin, M., Bonnet, S. \& Hess, W. R. Succession within the prokaryotic communities during the VAHINE mesocosms experiment in the New Caledonia lagoon. Biogeosciences 13, 2319-2337 (2016).

98. Lucas, J. et al. Short-Term Dynamics of North Sea Bacterioplankton-Dissolved Organic Matter Coherence on Molecular Level. Front. Microbiol. 7, (2016). 
99. Stoecker, D., Gustafson, D., Baier, C. \& Black, M. Primary production in the upper sea ice. Aquat. Microb. Ecol. 21, 275-287 (2000).

100. Montresor, M., Lovejoy, C., Orsini, L., Procaccini, G. \& Roy, S. Bipolar distribution of the cyst-forming dinoflagellate Polarella glacialis. Polar Biol. 26, 186-194 (2003).

101. Stecher, A. et al. rRNA and rDNA based assessment of sea ice protist biodiversity from the central Arctic Ocean. Eur. J. Phycol. 51, 31-46 (2016).

102. Leeuwe, M. van et al. Microalgal community structure and primary production in Arctic and Antarctic sea ice: A synthesis. Elem Sci Anth 6, 4 (2018).

103. Lalande, C. et al. Variability in under-ice export fluxes of biogenic matter in the Arctic Ocean. Glob. Biogeochem. Cycles 28, 571-583 (2014).

104. Hoffmann, K., Hassenrück, C., Salman-Carvalho, V., Holtappels, M. \& Bienhold, C. Response of Bacterial Communities to Different Detritus Compositions in Arctic Deep-Sea Sediments. Front. Microbiol. 8, 266 (2017).

105. Beattie, A., Hirst, E. L. \& Percival, E. Studies on the metabolism of the Chrysophyceae. Comparative structural investigations on leucosin (chrysolaminarin) separated from diatoms and laminarin from the brown algae. Biochem. J. 79, 531-537 (1961).

106. Kappelmann, L. et al. Polysaccharide utilization loci of North Sea Flavobacteriia as basis for using SusC/D-protein expression for predicting major phytoplankton glycans. ISME J. 13, 76-91 (2019).

107. Humphry, D. R., George, A., Black, G. W. \& Cummings, S. P. Flavobacterium frigidarium sp. nov., an aerobic, psychrophilic, xylanolytic and laminarinolytic bacterium from Antarctica. Int. J. Syst. Evol. Microbiol. 51, 1235-1243 (2001).

108. Ardyna, M. et al. Under-Ice Phytoplankton Blooms: Shedding Light on the "Invisible" Part of Arctic Primary Production. Front. Mar. Sci. 7, (2020).

109. Alonso-Sáez, L. et al. Winter bloom of a rare betaproteobacterium in the Arctic Ocean. Front. Microbiol. 5, (2014).

110. Garneau, M.-È., Roy, S., Lovejoy, C., Gratton, Y. \& Vincent, W. F. Seasonal dynamics of bacterial biomass and production in a coastal arctic ecosystem: Franklin Bay, western Canadian Arctic. J. Geophys. Res. Oceans 113, (2008).

111. Hawley, A. K. et al. Diverse Marinimicrobia bacteria may mediate coupled biogeochemical cycles along eco-thermodynamic gradients. Nat. Commun. 8, 1507 (2017).

112. Trevena, A. J. \& Jones, G. B. Dimethylsulphide and dimethylsulphoniopropionate in Antarctic sea ice and their release during sea ice melting. Mar. Chem. 98, 210-222 (2006). 
113. Berdjeb, L., Parada, A., Needham, D. M. \& Fuhrman, J. A. Short-term dynamics and interactions of marine protist communities during the spring-summer transition. ISME J. 12, 1907-1917 (2018).

114. Lampitt, R. S., Salter, I. \& Johns, D. Radiolaria: Major exporters of organic carbon to the deep ocean. Glob. Biogeochem. Cycles 23, (2009).

115. Nejstgaard, J. C. et al. Zooplankton grazing on Phaeocystis: a quantitative review and future challenges. Biogeochemistry 83, 147-172 (2007).

116. Gutierrez-Rodriguez, A. et al. High contribution of Rhizaria (Radiolaria) to vertical export in the California Current Ecosystem revealed by DNA metabarcoding. ISME J. 13, 964-976 (2019).

117. Mühlenbruch, M., Grossart, H.-P., Eigemann, F. \& Voss, M. Mini-review: Phytoplanktonderived polysaccharides in the marine environment and their interactions with heterotrophic bacteria. Environ. Microbiol. 20, 2671-2685 (2018).

118. Kim, H. \& Ducklow, H. W. A Decadal (2002-2014) Analysis for Dynamics of Heterotrophic Bacteria in an Antarctic Coastal Ecosystem: Variability and Physical and Biogeochemical Forcings. Front. Mar. Sci. 3, (2016).

119. Luria, C. M., Amaral-Zettler, L. A., Ducklow, H. W. \& Rich, J. J. Seasonal Succession of Free-Living Bacterial Communities in Coastal Waters of the Western Antarctic Peninsula. Front. Microbiol. 7, (2016).

120. Bowman, J. S., Amaral-Zettler, L. A., J. Rich J, M. Luria C \& Ducklow, H. W. Bacterial community segmentation facilitates the prediction of ecosystem function along the coast of the western Antarctic Peninsula. ISME J. 11, 1460-1471 (2017).

121. Levinsen, H. \& Nielsen, T. G. The trophic role of marine pelagic ciliates and heterotrophic dinoflagellates in arctic and temperate coastal ecosystems: A cross-latitude comparison. Limnol. Oceanogr. 47, 427-439 (2002).

122. Olli, K. et al. Food Web Functions and Interactions During Spring and Summer in the Arctic Water Inflow Region: Investigated Through Inverse Modeling. Front. Mar. Sci. 6, (2019).

123. Svensen, C. et al. Zooplankton Communities Associated With New and Regenerated Primary Production in the Atlantic Inflow North of Svalbard. Front. Mar. Sci. 6, (2019).

124. Preston, C. M., Durkin, C. A. \& Yamahara, K. M. DNA metabarcoding reveals organisms contributing to particulate matter flux to abyssal depths in the North East Pacific ocean. Deep Sea Res. Part II Top. Stud. Oceanogr. 173, 104708 (2020).

125. Taylor, J. D. \& Cunliffe, M. Coastal bacterioplankton community response to diatom-derived polysaccharide microgels. Environ. Microbiol. Rep. 9, 151-157 (2017). 
126. Gómez-Gutiérrez, J., Kawaguchi, S. \& Nicol, S. Epibiotic suctorians and enigmatic ecto- and endoparasitoid dinoflagellates of euphausiid eggs (Euphausiacea) off Oregon, USA. J. Plankton Res. 31, 777-785 (2009).

127. Buchholz, F., Werner, T. \& Buchholz, C. First observation of krill spawning in the high Arctic Kongsfjorden, west Spitsbergen. Polar Biol. 35, 1273-1279 (2012).

128. Chantangsi, C. et al. Fusiforma themisticola n. gen., n. sp., a New Genus and Species of Apostome Ciliate Infecting the Hyperiid Amphipod Themisto libellula in the Canadian Beaufort Sea (Arctic Ocean), and Establishment of the Pseudocolliniidae (Ciliophora, Apostomatia). Protist 164, 793-810 (2013).

129. Cardman, Z. et al. Verrucomicrobia: candidates for polysaccharide-degrading bacterioplankton in an Arctic fjord of Svalbard. Appl. Environ. Microbiol. 80, 3749-3756 (2014).

130. Landa, M. et al. Major changes in the composition of a Southern Ocean bacterial community in response to diatom-derived dissolved organic matter. FEMS Microbiol. Ecol. 94, (2018).

131. Comeau, A. M., Li, W. K., Tremblay, J. E., Carmack, E. C. \& Lovejoy, C. Arctic Ocean microbial community structure before and after the 2007 record sea ice minimum. PLOS ONE 6, e27492 (2011).

132. Morris, R. M., Frazar, C. D. \& Carlson, C. A. Basin-scale patterns in the abundance of SAR11 subclades, marine Actinobacteria (OM1), members of the Roseobacter clade and OCS116 in the South Atlantic. Environ. Microbiol. 14, 1133-1144 (2012).

133. Lalande, C., Bauerfeind, E., Nöthig, E.-M. \& Beszczynska-Möller, A. Impact of a warm anomaly on export fluxes of biogenic matter in the eastern Fram Strait. Prog. Oceanogr. 109, 70-77 (2013).

134. Reintjes, G. et al. Short-term changes in polysaccharide utilization mechanisms of marine bacterioplankton during a spring phytoplankton bloom. Environ. Microbiol. 22, 1884-1900 (2020).

135. Piontek, J., Sperling, M., Nöthig, E.-M. \& Engel, A. Regulation of bacterioplankton activity in Fram Strait (Arctic Ocean) during early summer: The role of organic matter supply and temperature. J. Mar. Syst. 132, 83-94 (2014).

136. Dybwad, C. et al. Carbon Export in the Seasonal Sea Ice Zone North of Svalbard From Winter to Late Summer. Front. Mar. Sci. 7, (2021).

137. Glud, R. N., Rysgaard, S., Turner, G., McGinnis, D. F. \& Leakey, R. J. G. Biological- and physical-induced oxygen dynamics in melting sea ice of the Fram Strait. Limnol. Oceanogr. 59, 1097-1111 (2014). 
138. Balmonte, J. P., Teske, A. \& Arnosti, C. Structure and function of high Arctic pelagic, particleassociated and benthic bacterial communities. Environ. Microbiol. 20, 2941-2954 (2018).

139. Vernet, M., Richardson, T. L., Metfies, K., Nöthig, E.-M. \& Peeken, I. Models of Plankton Community Changes during a Warm Water Anomaly in Arctic Waters Show Altered Trophic Pathways with Minimal Changes in Carbon Export. Front. Mar. Sci. 4, (2017).

140. Wollenburg, J. E. et al. Ballasting by cryogenic gypsum enhances carbon export in a Phaeocystis under-ice bloom. Sci. Rep. 8, 7703 (2018).

141. Shiozaki, T. et al. Factors Regulating Nitrification in the Arctic Ocean: Potential Impact of Sea Ice Reduction and Ocean Acidification. Glob. Biogeochem. Cycles 33, 1085-1099 (2019).

142. de Sousa, A. G. G. et al. Diversity and Composition of Pelagic Prokaryotic and Protist Communities in a Thin Arctic Sea-Ice Regime. Microb. Ecol. 78, 388-408 (2019).

143. Parada, A. E., Needham, D. M. \& Fuhrman, J. A. Every base matters: assessing small subunit rRNA primers for marine microbiomes with mock communities, time series and global field samples. Environ. Microbiol. 18, 1403-1414 (2016).

144. Martin, M. Cutadapt removes adapter sequences from high-throughput sequencing reads. EMBnet.journal 17, 10-12 (2011).

145. Callahan, B. J. et al. DADA2: High-resolution sample inference from Illumina amplicon data. Nat. Methods 13, 581-583 (2016).

146. von Appen, W.-J. Physical oceanography and current meter data (including raw data) from FRAM moorings in the Fram Strait, 2016-2018. (2019) doi:10.1594/PANGAEA.904565.

147. Richter, M. E., Appen, W.-J. von \& Wekerle, C. Does the East Greenland Current exist in the northern Fram Strait? Ocean Sci. 14, 1147-1165 (2018).

148. Spreen, G., Kaleschke, L. \& Heygster, G. Sea ice remote sensing using AMSR-E 89-GHz channels. J. Geophys. Res. Oceans 113, (2008).

149. R Core Team. R: A language and environment for statistical computing. (R Foundation for Statistical Computing (Vienna, Austria), 2018). 
$\mathbf{a}$

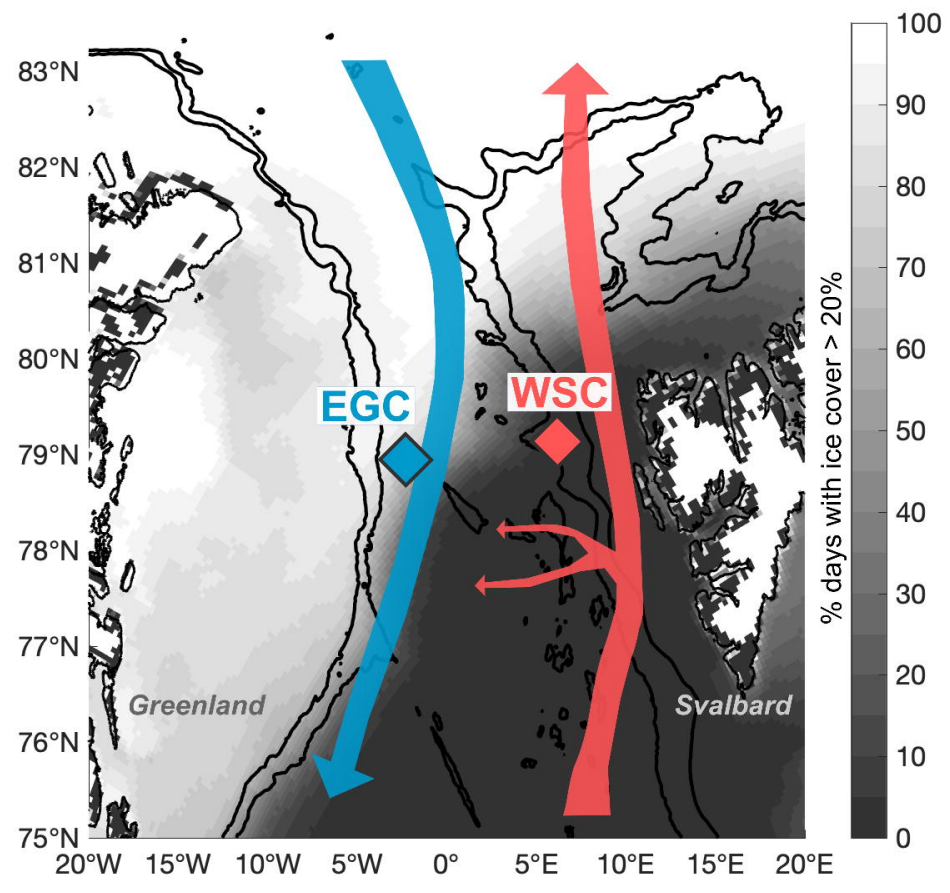

b
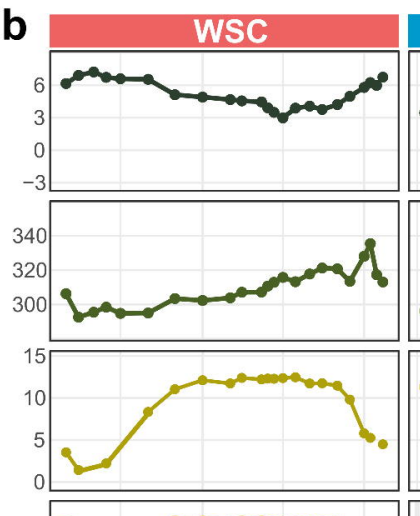

TNWN
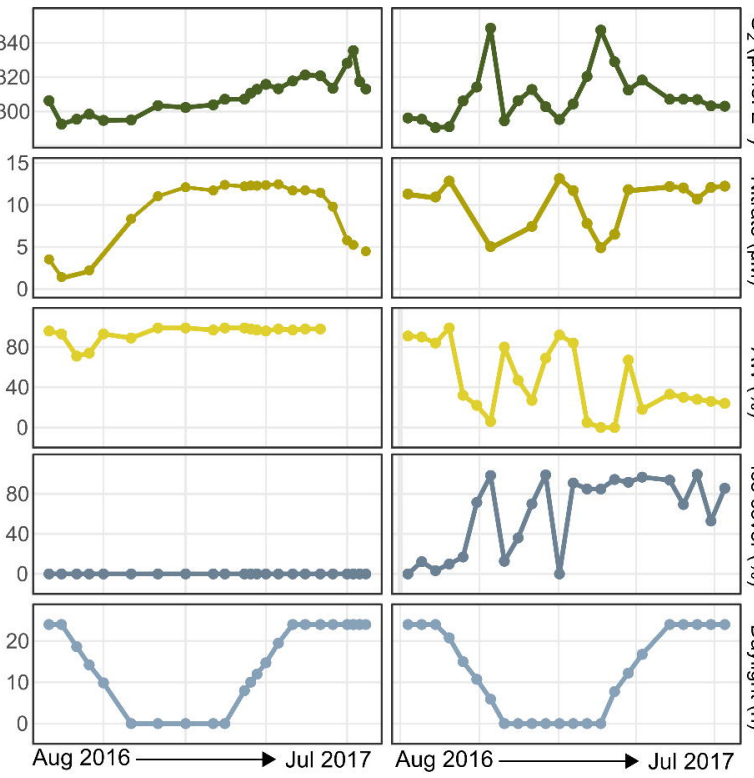


40

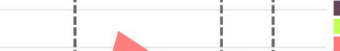

Bacillariophyta

Prymnesiophyceae Syndiniales RAD-C

Pirsonia clade MAST-3

\section{Bacteria / Archaea}

Flavobacteriales

Rhodospirillales

Rhodobacterales Nitrosopumilales

Gammaproteo_uc Verrucomicrobiae Planctomycetales

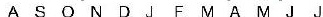

A S 


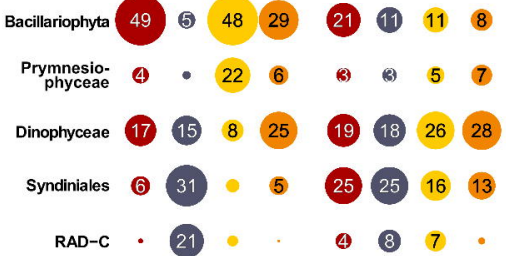

b Raphid-pennate Mediophyceae Phaeocystaceae Araphid-pennate Mamiellaceae Gymnodiniaceae Strombidiidae M Chytriodiniaceae Toveliaceae Pelagophyceae Suessiacoao Coscinodiscophyceae Ceratiaceae

Heterocapsaceae Pelagomonadaceae Opalinopsidae Syndiniales (Group I-1) Syndiniales (Group II-7) RAD-C RAD-B-Group-IV MAST-3I

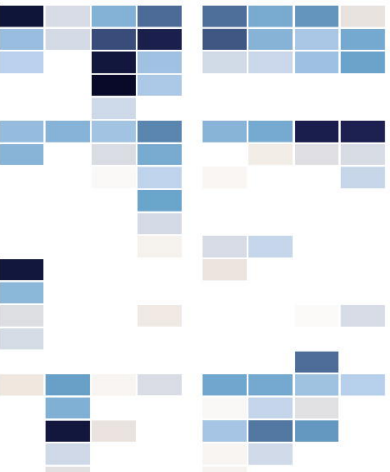

Pirsonia clade

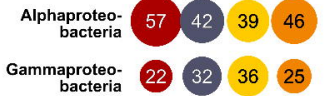
bacteria

Bacteroidia

Nitrososphaeria Verruco-
microbiae

14 4 $14 \quad 25$

. 53.

$\begin{array}{llll}7 & 5 & 4 & 3\end{array}$

65

SAR11 Clade I SAR86 clade Thioglobaceae

Nitrincolaceae Flavobacteriaceae Cryomorphaceae OCS116 clade Rhodobacteraceae SAR116 clade AEGEAN-169 Magnetospiraceae Defluviicoccales_uc Nitrosopumilaceao

Dadabacteriales Arctic97B-4 Rubritaleaceae Nitrospinaceae Pirollulaceao

Gammaproteo_uc Woesoiaceao Colwelliaceae SAR406

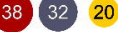

$3 4 \longdiv { 3 2 } \quad 4 5$

(11) 15

16

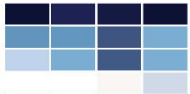

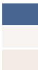
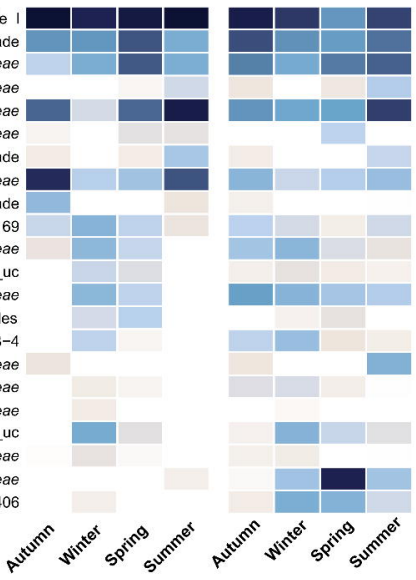

$\%$ Read Abundance 
WSC

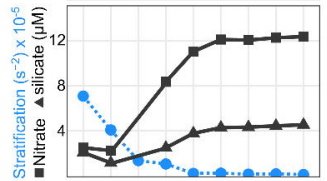

b

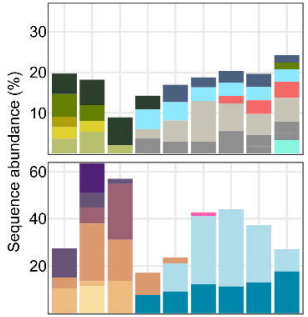

c

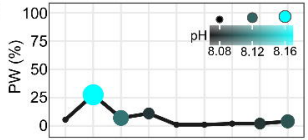

$A S O N D J A M A$
EGC
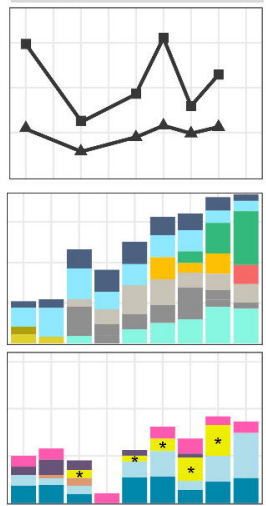

Corethron

Fraguariopsis

* ice taxa

Proboscia
Chaetoceros

Luteolibacter

Magnetospira

Dadabacteria SAR406_uC Colwellia

Flavobacterium

Gamma uc

Nitrosopumilus

Pseudo-nitzschie RAD-C Rhizosolenia Syndiniales Tripos

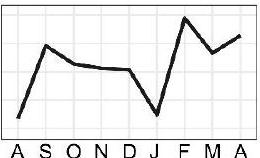


WSC

a

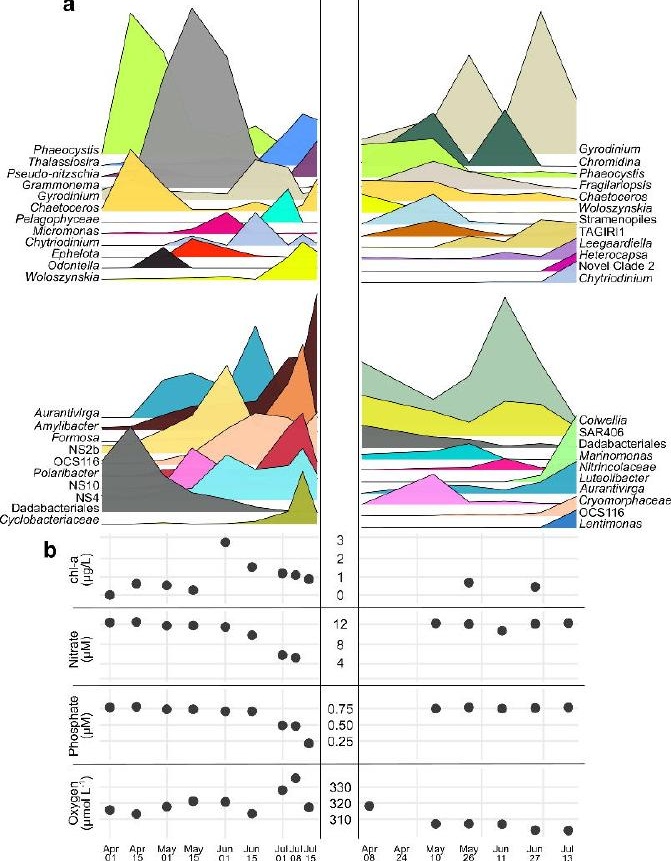

